\title{
EDUCAÇÃO FÍSICA ESCOLAR E FILANTROCAPITALISMO: o "Impulsiona" e a privatização de uma narrativa curricular
}

\author{
Renato Cavalcanti Novaes \\ Centro de Instrução Almirante Alexandrino, CIAA/MARINHA, Brasil \\ Antonio Jorge Gonçalves Soares \\ Universidade Federal do Rio de Janeiro - UFRJ, Brasil \\ Theresa Adrião \\ Universidade Estadual de Campinas - UNICAMP, Brasil \\ Silvio de Cassio Costa Telles \\ Universidade Federal do Rio de Janeiro - UFRJ, Brasil \\ Resumo
}

\begin{abstract}
O alinhamento das políticas públicas educacionais no Brasil com o modelo global econômico e cultural neoliberal tem produzido novas formas de significar o processo de escolarização. Recentemente, observou-se a emergência de atores sociais enraizados no mercado e provenientes do setor privado na implementação de programas de currículo. Na Educação Física, exemplar é o programa Impulsiona, criado em 2017 pelo Instituto Península, braço filantrópico da Península Participações. Em parceria com o Ministério da Educação, o Impulsiona oferece formação docente gratuita para fomentar o esporte nas escolas. Neste texto, por meio da análise de documentos institucionais, analisamos a narrativa produzida pelo Impulsiona para a Educação Física escolar. Demonstramos, primeiramente, o alcance da rede de influência desse ator e a constituição de um tipo muito específico de privatização que borra as fronteiras entre o público e o privado. Em seguida, desnaturalizamos a narrativa de uma Educação Física atravessada por um ideal performático e que assume contornos esportivizantes, acríticos, tecnocráticos e neo-higiênicos a serviço da formação de capital humano para o mercado. Por fim, reforçamos que esse discurso, marcado por uma racionalidade neoliberal, pode acarretar em um esvaziamento curricular dessa disciplina.
\end{abstract}

Palavras-chave: Educação Física escolar; Neoliberalismo; Currículo; Filantrocapitalismo; Privatização; BNCC.

\begin{abstract}
The alignment of the educational public policies in Brazil with the neoliberal global economic and cultural model has produced new ways of meaning the schooling process. Recently, the emergence of social actors rooted in the market and coming from the private sector has been observed due to the implementation of public curriculum policies. One of those actors in school Physical Education is the "Impulsiona", an institution created in 2017 by "Instituto Península", a philanthropic arm of "Península Participações". In a partnership with the Ministry of Education, "Impulsiona" offers free teacher training to promote sport in schools. In this text we analyze the narrative produced by Impulsiona for Physical Education in the scenario of neoliberal curriculum policies. First, we demonstrate the reach of this program's network of influence and the constitution of a very specific type of privatization that blurs the boundaries between public and private. Then, we denaturalize the narrative of a Physical Education crossed by a performative ideal which assumes sportive, uncritical, technocratic and neo-hygienic contours at the service of the formation of human capital for the market. Finally, we reinforce that this discourse, marked by a neoliberal rationality, can lead to a curricular voidance of this school subject.
\end{abstract}

Keywords: School Physical Education; neoliberalism; curriculum; philanthrocaptalism; privatization; BNCC.

ISSN 1645-1384 (online) www.curriculosemfronteiras.org 


\section{Introdução}

A reestruturação econômica e educacional global nas últimas décadas tem produzido novas formas de significar o processo de escolarização no Brasil (Ball, 2013; Macedo, 2014). Principalmente a partir da década de 1990, foi possível observar um alinhamento das políticas públicas nacionais com o modelo econômico e cultural neoliberal ${ }^{1}$ que se espalhou através de reformas educativas em diversos países, um fenômeno internacional conhecido como $\mathrm{Germ}^{2}$, sigla em inglês para "movimento global de reforma da educação" (Sahlberg, 2016). Tais reformas se caracterizam pela centralização de um currículo prescritivo, da avaliação em larga escala e da formação docente pautada em um fazer técnico (Ball, 2014); e ocorrem no contexto de desinvestimento do Estado na educação pública e de expansão da atuação de atores privados/corporativos nesse setor (Tarlau; Moeller, 2020).

As reformas neoliberais remetem a uma transferência de valores econômicos para a educação, tais como eficiência e competitividade entre alunos, professores e escolas. Para o neoliberalismo, o mercado deve nortear as políticas de estado, pois há uma "interiorização da lógica da concorrência do mercado pelo Estado" (Laval, 2020, p. 43). As recentes políticas educacionais, portanto, não podem ser analisadas apenas a partir do ponto de vista do Estado local, pois a educação torna-se uma questão global e de mercado, além de uma oportunidade de negócios rentáveis para diferentes investidores para além das fronteiras nacionais (Ball, 2014). Dessa forma,

[..] em diferentes graus, em diferentes países, o setor privado ocupa agora uma gama de funções e de relações dentro do Estado e na educação pública em particular, como patrocinadores e benfeitores, assim como trabalham como contratantes, consultores, conselheiros, pesquisadores, fornecedores de serviços e assim por diante; tanto patrocinando inovações (por ação filantrópica) quanto vendendo soluções e serviços de políticas para o Estado, por vezes de forma relacionadas (Ball, 2014, p. 181).

Nesse contexto, Macedo (2014, 2016, 2019a, 2019b), Adrião (2017, 2018) e Avelar e Ball (2017) indicam o protagonismo de atores sociais enraizados no mercado em articulação com entes públicos na reforma curricular que culminou em dezembro de 2017 na publicação da Base Nacional Comum Curricular (BNCC). Entre esses atores estão as mais diferentes empresas que, em princípio, não possuem tradição com a escolarização e que atuam por meio de suas fundações sociais, como: Itaú [Unibanco], Bradesco, Santander, Gerdau, Natura, Volkswagen, Victor Civita, Roberto Marinho, Lemann e Península, entre outras. Além desses, outro grupo de atores são os movimentos organizados pela sociedade civil com diferentes perspectivas de atuação, como: Todos pela Educação, Amigos da Escola e CENPC (Centro de Estudos e Pesquisas em Educação, Cultura e Ação Comunitária); que também contam com a participação das fundações supramencionadas, além de empresários, grandes corporações e outras personalidades (Macedo, 2016). Nesse sentido, a BNCC representa a 
expressão mais acabada da gestão corporativa da educação expressa na apropriação da gestão pública por setores privados (Adrião; Peroni, 2018).

Emerge, assim, uma nova configuração de atuação do mercado no setor público, que Ball (2014) denomina de "filantrocapitalismo", também conhecido por filantropia de risco Venture philantropy - ou "filocapitalismo" (Adrião, 2018). Há, com isso, uma desvinculação do sentido tradicional de filantropia para um outro que implica ganhos diretos, no caso das corporações investidas no negócio da educação (edu-business), e/ou indiretos, em que os atores corporativos se inserem no jogo político de decisões sobre políticas públicas e produzem novos sentidos para a educação alinhados à lógica do mercado.

A fim de esclarecer as condições de atuação dos grupos filantrocapitalistas, Bishop e Green (2008) destacam a relação direta do crescimento desse segmento com a concentração da riqueza e do poder em tempos recentes (Dowbor, 2017), no qual se sobressai a exigência de retorno, inclusive financeiro, para os investimentos realizados nas "causas" filantrópicas (Adrião, 2020). A esse respeito, tem sido evidente o papel catalizador exercido pela Global Network of Foundations Working for Development (netFWD), rede de filantropos globais criada em 2014 no âmbito da OCDE e integrada pelos brasileiros Instituto Ayrton Senna e Fundação Itaú Social (Adrião, 2018).

Uma das facetas desses grupos vinculados ao setor privado é atuar diretamente em algumas disciplinas-chave da escolarização. No caso da Educação Física, Novaes et al. (2021) identificaram o alinhamento do texto sobre esse componente curricular na BNCC com outras políticas públicas, entre eles o "Impulsiona Educação Esportiva", um programa de formação continuada de professores de Educação Física escolar (EFE) financiado por uma instituição filantrópica em parceria com o Ministério da Educação (MEC). Segundo o site eletrônico do "Impulsiona", esse programa oferece cursos e eventos online e presenciais que visam fomentar o esporte nas escolas, principalmente na rede pública, tendo capacitado mais de 145 mil professores de Educação Física desde sua criação e atingido assim mais de 49 mil escolas em mais de cinco mil municípios em todos os estados brasileiros ${ }^{2}$.

Nesse cenário, este texto analisa a narrativa produzida pelo programa Impulsiona para a EFE. O texto está organizado da seguinte forma: na primeira seção construímos uma etnografia da rede política da referida instituição, mapeando suas relações com os setores púbico e privado. Na seção seguinte, demonstramos a transição para uma nova forma de conceber a EFE alinhada à lógica neoliberal, articulando as relações de poder com a produção de saberes. Por fim, reforçamos a potência dos discursos produzidos pelo Impulsiona, uma vez que se articula numa densa rede de decisões políticas, atravessada por uma racionalidade neoliberal, alinhada às mais recentes políticas públicas de currículo.

\section{Etnografia das redes políticas}

Para Ball (2014), a atuação de atores sociais provenientes do setor privado e engajados na esfera pública não pode ser compreendida apenas a partir de uma polarização entre o 
público e o privado. Para ele esses grupos se articulam em redes políticas/discursivas que borram as fronteiras entre o público e o privado, formando uma espécie de "comunidade política". Tais redes políticas que, de alguma maneira, sempre existiram, capilarizaram-se quantitativa e qualitativamente com as recentes reformas neoliberais, constituindo redes discursivas que transferem para a educação valores de uma lógica empresarial.

O mapeamento dessas redes políticas, assim como descrito por Ball (2014), pretende destacar a relação entre o mercado da educação, a filantropia de risco, as agências não governamentais e os setores público e privado. Assim, pretendemos aqui compreender o contexto da rede política na qual o Impulsiona se insere. Para tal, apoiamo-nos no que Ball (2014) denomina de "etnografia de redes", que consiste em uma análise das relações dos diferentes atores da rede política do Impulsiona elaborada a partir de informações obtidas no próprio site do programa e dos seus parceiros, assim como em documentos e notícias de caráter público divulgadas online.

O Impulsiona foi criado em 2017 pelo Instituto Península, instituição filantrópica que atua nos setores da educação e do esporte. Criado em 2010, esse instituto tem como missão a "melhoria da qualidade da educação brasileira", sendo mantenedor de quatro iniciativas: o próprio Impulsiona, o Núcleo de Alto Rendimento Esportivo de São Paulo (NAR-SP), o Instituto Singularidades e o Vivescer ${ }^{3}$.

No quadro de atuação do esporte, o Impulsiona foi adicionado ao NAR-SP, um centro de formação gratuito para atletas profissionais, inaugurado em 2011 pelo Instituto Península. Voltado para "estudo, avaliação, prescrição de treinamento esportivo e capacitação de técnicos e preparadores físicos, focado no alto rendimento de atletas e equipes profissionais" recebe anualmente mais de mil esportistas de 70 diferentes modalidades ${ }^{4}$. Após um convênio com a Secretaria Municipal de Esportes de São Paulo em 2014 ${ }^{5}$, o NAR-SP inaugurou, no ano seguinte, um novo centro que conta com instalações como pista de atletismo, campo de rugby/futebol oficiais, pista interna, área de lutas, academia, refeitório e auditório. Ademais, o NAR-SP oferece cursos na área do alto rendimento e suporte para atletas através de projetos fomentados pelas Leis de Incentivo ao Esporte $^{6}$.

No campo da educação, o Instituto Península atua por meio de duas iniciativas: o Instituto Singularidades e o Vivescer. O Singularidades é uma instituição de Ensino Superior sem fins lucrativos, fundada em 2001, que foi incorporada em 2010 pelo Instituto Península. Oferece diferentes cursos, na maior parte pagos, de extensão, graduação e pós-graduação latu sensu, voltados para a área de educação. Ademais, o instituto presta consultorias de educação para o ensino público e privado. De acordo com o site do Instituto Singularidades ${ }^{7}$, a instituição já atendeu mais de 50 mil educadores públicos com projetos de consultoria e 69 mil professores com cursos online.

Já o Vivescer consiste em uma plataforma/comunidade gratuita que oferece soluções digitais para professores e gestores em todo o Brasil. Teve início com uma escola experimental de Educação Infantil (Escola da Toca), cujo modelo foi replicado numa escola pública no interior do estado de São Paulo e, desde 2020, tem se expandido virtualmente, com mais de 10 mil professores inscritos em todo o país ${ }^{8}$. 
O Instituto Península, portanto, opera de diferentes maneiras no campo da educação e do esporte. Além das ações citadas, publica livros digitais sobre formação docente em parceria com outras instituições filantrópicas ${ }^{9}$, tais como a Fundação Lemann ${ }^{10}$, o Instituto Ayrton Senna e a Fundação Santillana ${ }^{11}$. Apoia ainda, logística e/ou financeiramente, outros programas e projetos nas áreas da educação e do esporte: o Instituto Superior de Educação de São Paulo (ISESP), o Instituto Fazenda da Toca, o Instituto Natura, o Todos pela Educação, o Centro de Inovação para Educação Brasileira (CIEB), o Instituto Verdescola, o Atletas pelo Brasil, a Associação Parceiros da Educação, o Instituto Rodrigo Mendes, o Programa de Bolsas (Formar +), o Ensina Brasil; assim como oferece bolsas para alunos em parceria com a Sociedade Beneficente Hospital Albert Einstein e o Instituto Lourenço Castanho (Instituto Península, 2019).

Vale dizer que muitos dos atores descritos acima, em especial a Fundação Lemann, o Instituto Ayrton Senna, a Fundação Santillana, entre outros, foram fundamentais na implementação da BNCC, o que representa um monumento do intenso ingresso de atores "filantrópicos" nas políticas públicas brasileiras (Adrião, 2017, 2018; Macedo, 2014, 2016, 2018, 2019a, 2019b). Esse protagonismo, no que se refere à BNCC, configurou-se através de:

[...] financiamento e coordenação de reuniões em que as versões dos documentos foram debatidas e produzidas; formação de pesquisadores em centros internacionais pró-centralização curricular como Standford; realização de pesquisas que sustentaram a necessidade de currículos nacionais; financiamento de seminários que narraram exitosas experiências internacionais, produção de materiais para a implementação dos currículos; contratação de grupos internacionais para avaliar a experiência em curso, entre muitas outras (Macedo, 2019b, p. 1122).

Apenas para ilustrar como as instituições descritas até aqui estiveram envolvidas nessa trama, desatacamos o evento sobre a BNCC e a formação de professores, ocorrido na Fundação Getúlio Vargas (FGV) no Rio de Janeiro, em 2018, cuja meta foi discutir os desafios de implementação da base nacional e da formação de professores. Participaram representantes do MEC, do Teachers College/Columbia University e da Fundação Lemann, sendo o Instituto Singularidades a única instituição brasileira de formação de professores presente (MACEDO, 2018). Além desse, o Instituto Península apoiou(a) diferentes "movimentos" que tiveram papel fundamental na implementação da BNCC, como os já citados Todos pela Educação e Centro de Inovação para a Educação Brasileira (CIEB).

Diante do exposto, percebe-se que o Instituto Península investe em diversas frentes no campo da educação e do esporte para além do Impulsiona. Seus recursos são obtidos principalmente a partir de:

(a) doações voluntárias, legados, contribuições, auxílios, direitos ou créditos e outras aquisições proporcionadas por quaisquer pessoas físicas ou jurídicas; (b) eventuais rendas provenientes de bens ou de prestação de serviços; (c) subvenções 
dos poderes públicos federal, estadual e municipal; (d) contribuições em bens móveis e imóveis; (e) eventos promovidos pelo Instituto; (f) eventos organizados para levantamento de fundos para programas mantidos pelo Instituto; $(\mathrm{g})$ acordos e convênios celebrados com o poder público; (h) outras receitas decorrentes de atos líticos e compatíveis com a finalidade do Instituto e com o estatuto social (Instituto Península, 2019).

Logo, o Instituto Península é uma entidade sem fins lucrativos que recebe recursos, principalmente, do setor privado que, por sua vez, destina parte de seus impostos para ações filantrópicas por meio de renúncia fiscal ${ }^{12}$. Essa é a estratégia tipicamente adotada pelos atores dessa sociabilidade política repaginada que atua intensamente nas políticas públicas, o que, segundo Macedo (2016, p. 12), "classicamente permite a gestão privada de verbas públicas". Nesse sentido, amplia-se a necessidade de compreender como tais redes que se baseiam no altruísmo e no mercado, realizam ações como setor privado utilizando recursos públicos, dinheiro esse advindo da renúncia fiscal do Estado.

Desse modo, a rede de atuação política do Impulsiona e do Instituto Península remete a sua mantenedora: a Península Participações. Fundada em 2006 pelo empresário e entusiasta do esporte Abílio Diniz ${ }^{13}$; trata-se de uma empresa de investimento privado que gerencia os ativos da família Diniz, estimados em torno de 10 bilhões de reais ${ }^{14}$. A Península Participações investe em ativos estratégicos (Carrefour Brasil, Carrefour Global e BRF, esse último fruto da fusão entre Perdigão e Sadia); private equity (ou "patrimônio privado", ou seja, "investimento em participações de empresas em setores como educação, consumo e varejo"); imóveis, dentre outros ${ }^{15}$.

Os primeiros investimentos após a formação da Península Participações foram justamente no mercado da educação, mais especificamente com a compra de uma participação na Mind $\mathrm{Lab}^{16}$, empresa envolvida na formação de professores e na elaboração de ambientes informáticos, principalmente no ramo de "jogos educativos". Fundada em Israel no ano de 1994, a Mind Lab já atuou em mais de 20 países e, desde 2006, no Brasil, realizou parcerias "com mais de mil instituições no setor público e privado" 17 .

Outro investimento significativo no mercado da educação, realizado pela empresa da família Diniz sem valores divulgados publicamente, foi a aquisição de participações na Anima Educação S.A. --grupo educacional que abrange oito instituições de ensino superior e que atende aproximadamente 140 mil estudantes em sete estados no Brasil. Com isso passou a ser um dos maiores grupos privados que investe no setor da educação ${ }^{18}$. Dessa forma, tanto a Anima quanto a Mind Lab fazem parte do portfólio de private equity conhecido da Península Participações no ramo da educação, que, de alguma forma, se articula com os investimentos em instituições filantrópicas do Instituto Península (Impulsiona, NAR-SP, Singularidades e Vivescer), por convergirem em uma visão de educação alinhada à lógica do mercado, sendo que, no caso das instituições filantrópicas, sua ação é direcionada majoritariamente para os setores dos serviços públicos de educação.

Muito embora o foco da nossa análise seja o Impulsiona, a descrição da rede política do Instituto Península e demais braços filantrópicos é importante para compreendermos o 
contexto mais amplo de atuação do Impulsiona. Estamos diante de um quadro geral de filantropia da Península Participações que, por meio do Instituto Península, age em articulação com entes públicos para oferecer seus programas, cursos e consultorias e se articula com diferentes negócios no mercado da educação.

O Impulsiona possui com o MEC uma parceria estratégia para a difusão de seus $\operatorname{conteúdos~}^{19}$. Seus cursos são chancelados e certificados pelo Ministério da educação e também alocados no Ambiente Virtual de Aprendizagem do Ministério da Educação ${ }^{20}$ (AVAMEC) e na e-Proinfo ${ }^{21}$, outra plataforma do governo federal voltada para a formação de professores em todo o Brasil. Além disso, em 2015, o Impulsiona e o Instituto Península foram responsáveis pela criação da categoria Esporte como Estratégia de Aprendizagem no prêmio Professores do Brasil ${ }^{22}$, premiação promovida pelo MEC desde 2005.

Nas esferas estaduais e municipais, o Impulsiona possui parcerias com a Secretaria de Educação do Ceará, a Secretaria Estadual de Educação de Minas Gerais (SME-MG) e a Secretaria Municipal de Educação de São Paulo (SME-SP), que disponibilizam seus cursos (online) diretamente para os professores das respectivas redes ${ }^{23}$, assim como oferecem cursos presenciais. A título de exemplo, de acordo com a coordenadora do Impulsiona, Verônica Fonseca, um de cada três professores de Educação Física do estado de Minas Gerais já realizou cursos na plataforma ${ }^{24}$.

Em parceria com a SME-SP, cidade onde o Impulsiona está sediado, organizou em 2019 o " $1{ }^{\circ}$ Congresso de Educação Esportiva: o esporte e seu potencial transformador". Tal evento foi realizado em uma escola estadual no município de São Paulo, com professores e gestores da educação básica. $\mathrm{O}$ evento contou com a participação de nomes conhecidos do campo esportivo e acadêmico, como a ex-jogadora de basquete Magic Paula, a filósofa Viviane Mosé e a professora Kátia Rúbio, da Universidade de São Paulo (USP) ${ }^{25}$.

Outras parcerias do Impulsiona são mais ocasionais, como no caso de um evento organizado com o "Instituto Trevo", em dezembro de 2019, na cidade do Rio de Janeiro. O "Instituto Trevo" é uma organização sem fins lucrativos que atua com "esporte educação" e "empreendedorismo social". Desde 2012 é parceiro da Secretaria Municipal de Educação do Rio de Janeiro (SME-RJ) na administração de escolas vocacionadas para o esporte, o antigo Ginásio Experimental Olímpico (GEO), atual Escola Municipal Olímpica Carioca $(\text { EMOC })^{26}$. Participaram do evento em questão (Figura 1) professores da rede pública dos municípios do Rio de Janeiro e de São Paulo em mesas de diálogo com diferentes convidados, sobre o tema "Mente, Corpo e Emoção: Inovando em Educação". 
Figura 1 - Evento organizado pelo Instituto Trevo e pelo Impulsiona.

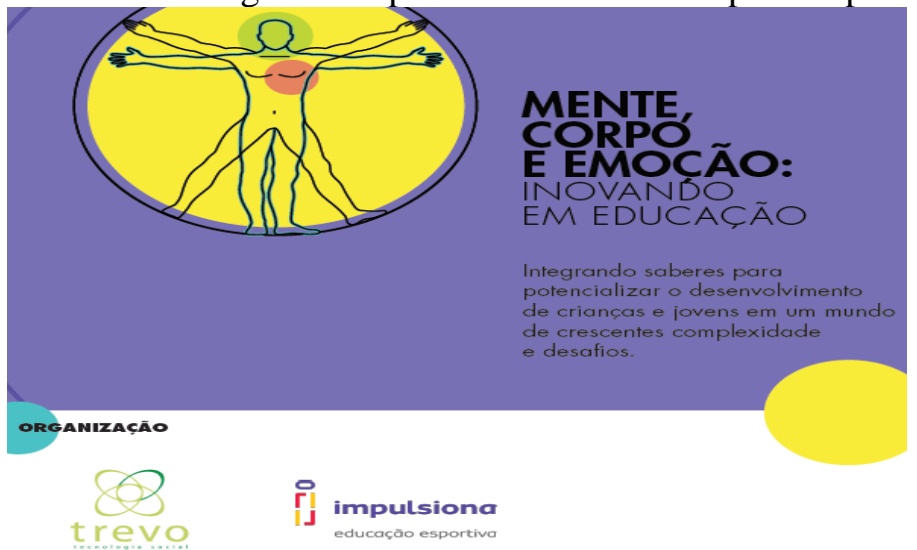

Fonte: Acervo pessoal dos autores ${ }^{27}$.

O "Impulsiona" possui ainda parcerias com a União Nacional dos Dirigentes Municipais de Educação (UNDIME) e com o Conselho Nacional de Secretários de Educação (CONSED), ambas sociedades civis sem fins lucrativos, formadas pelos dirigentes das secretarias municipais e estaduais de educação de todo o território nacional ${ }^{28}$. Tanto a UNDIME quanto o CONSED ${ }^{29}$ possuem "parcerias estratégicas" com a vasta rede de instituições filantrópicas e de movimentos civis já citada, como a Fundação Lemann, o Instituto Ayrton Senna, o Amigos da Escola, o Todos pela Educação, o Centro de Estudos e Pesquisas em Educação, Cultura e Ação Comunitária (CENPEC), entre tantas outras.

Para conferir ainda mais materialidade à atuação do Impulsiona e do Instituto Península nessa rede, apontamos sua inserção no programa Profissão Docente, voltado para a formação de professores da rede pública em parceria com o MEC, o CONSED e a UNDIME, assim como outras instituições filantrópicas, a saber: a Fundação Lemann, o Itaú Social, a Fundação Telefônica, o Instituto Natura, o Instituto Unibanco e o Todos pela Educação ${ }^{30}$, como já apontamos sua relação com uma rede de instituições.

Além das parcerias destacadas, o site do Impulsiona declara ainda existirem os seus nomeados "parceiros de formação", organizações que atuam em colaboração com o programa na organização de conteúdos e $\operatorname{cursos}^{31}$. São eles: o Comitê Paralímpico Brasileiro (CPB), a Confederação Brasileira de Atletismo (CBAt), a Confederação Brasileira de Hóquei sobre a Grama (CBHG), a Confederação Brasileira de Tênis (CBT) e o Instituto Rodrigo Mendes $^{32}$.

O Conselho Federal de Educação Física (CONFEF) é outra entidade que legitima a atuação do Impulsiona pela abrangência no campo da Educação Física. Além de divulgar os cursos do Impulsiona em seus boletins e revistas ${ }^{33}$ periodicamente, os dois integram o já citado prêmio Professores do Brasil do MEC na categoria esportiva ${ }^{34}$. Ademais, em 2018, firmaram parceria no congresso que marcou os vinte anos da regulamentação da profissão de educação física ${ }^{35}$. 
Vale ressaltar que o Impulsiona está inserido numa rede política muito maior do que a descrita até então, uma vez que cada uma das instituições parceiras se articula em redes próprias, produzindo um efeito em teia muito mais denso e complexo que o descrito até aqui. O mapeamento que realizamos da rede política do Impulsiona, portanto, é parcial, uma vez que é dinâmico e, por vezes, pontual e eventual. A seguir, influenciados pelos modelos ilustrativos das etnografias de redes de Ball (2014), elaboramos a Figura 2 que visibiliza algumas das principais relações da rede política do Impulsiona. A finalidade do mapeamento dessa rede política foi revelar o alcance do Impulsiona, seja por parte das organizações sociais que integra o Instituto Península, seja por parte de suas parcerias diretas. Isso permite demonstrar como as ideias do Impulsiona são capazes de transitar com facilidade.

Figura 2 - Mapa da rede política do Impulsiona.

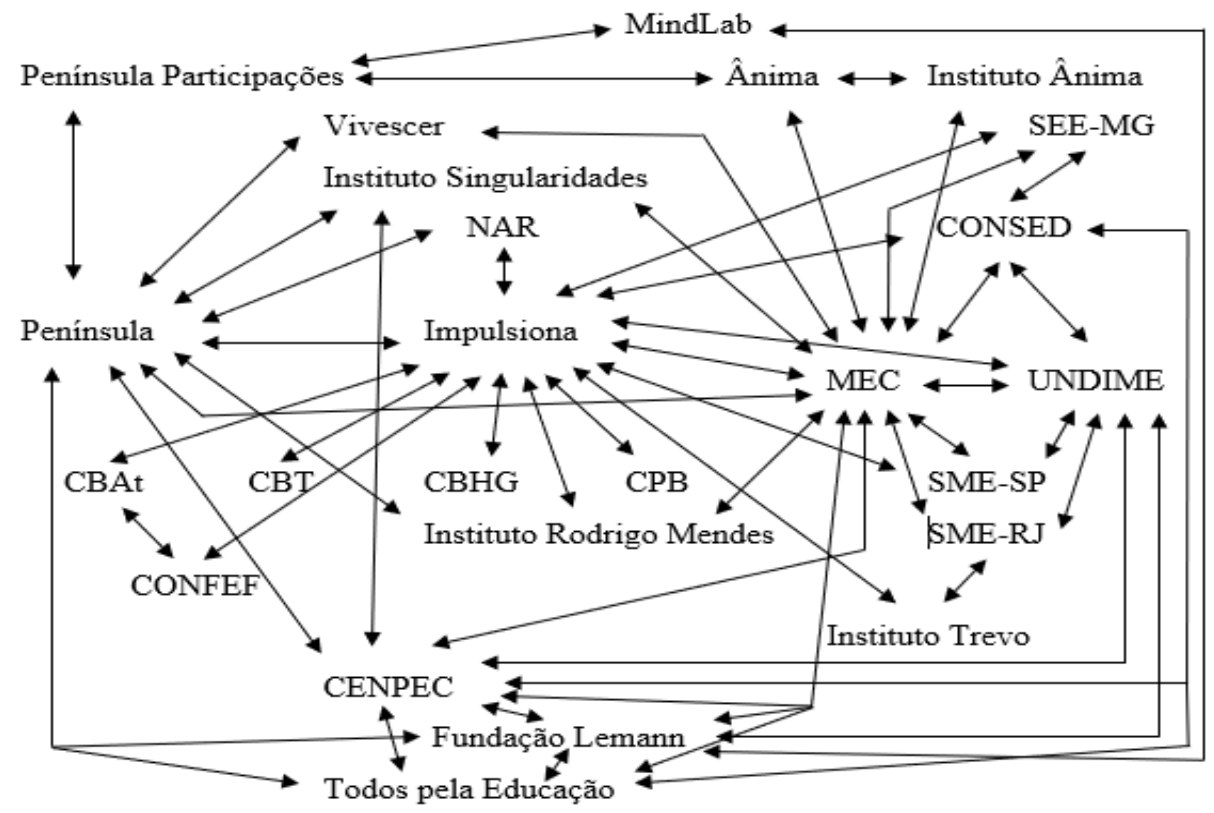

Fonte: os autores ${ }^{36}$.

No entanto, não devemos afirmar, segundo aponta Laval (2019), tratar-se de uma espécie de complô ou de uma trama da perspectiva neoliberal que descobriu a educação como um ativo rentável, mas sim:

[...] de uma construção muito eficaz, na medida em que não é possível identificar facilmente uma ou várias instâncias responsáveis por ela, o processo é difuso, tem múltiplas plataformas nacionais e internacionais cuja ligação não é clara à primeira vista, utiliza em geral vias técnicas e se apresenta com frequência com as melhores intenções éticas (p. 19). 
Com isso, não pretendemos implicar os interesses comerciais diretos da Península Participações na rede política descrita, apesar da relevância de tal informação, mas de conferir materialidade a essa rede na qual se insere o Impulsiona, uma vez que tais arranjos produzem discursos no campo da educação com efeitos bastante concretos, em especial na elaboração de políticas públicas de currículo, como no caso da BNCC, e na formação de professores para a subsequente implementação curricular, efeito que discutiremos na próxima seção sobre os discursos que circulam sobre a Educação Física no Impulsiona.

\section{A narrativa de uma Educação Física na rede neoliberal}

Ball (2010, 2014) distingue, no discurso das reformas neoliberais de currículo, a capilaridade das ideias de performance e performatividade. Entende-se "performance como medida de produtividade e desempenho" e "performatividade como tecnologia, cultura e modo de regulação" (Ball, 2010, p. 37). Para ele, o que está em jogo é uma luta pelo sentido de educação, marcado por uma transição de questões como "isso é verdadeiro?" ou "isso é justo" para “isso é útil, vendável, eficiente?” (Lyotard, 2015).

Assim, diversos autores (Saviani, 2008; Taubman, 2009; Laval, 2019) têm apontado a emergência de uma linguagem performática típica das reformas neoliberais de currículo que seguem o princípio universal da concorrência e que está "intimamente associada às noções de eficiência, desempenho e competência” (Laval, 2019, p. 69). Essas reformas se pautam em perspectivas eminentemente tecnocráticas, atualizando antigas terminologias psicopedagógicas ou tecnicistas do campo da educação.

Podemos, portanto, assumir que está em curso um movimento de transição em direção a uma nova forma de conceber as disciplinas escolares alinhada à lógica dos empreendimentos neoliberais. Enquanto na seção anterior realizamos um mapeamento das redes políticas do Impulsiona a fim de compreendermos seu alcance e funcionamento, nesta seção pretendemos compreender os discursos que circulam na rede e seus efeitos na produção de uma Educação Física fundamentada no princípio da performatividade sob o manto das políticas neoliberais para a educação.

\subsection{0 uso do esporte}

Nesse processo de desconstrução do sentido de EFE no Impulsiona, tomamos como ponto de partida sua missão:

Temos o objetivo estimular o uso do esporte como ferramenta educacional no desenvolvimento integral dos alunos. Queremos incentivar a prática de novas modalidades, trabalhar as competências socioemocionais e fortalecer a cultura esportiva [...] (Impulsiona, 2020a, grifo nosso). 
O programa do Impulsiona se dirige para a Educação Física como disciplina escolar e toma o esporte como a ferramenta educacional por excelência. Observemos que tratar o esporte como eixo curricular no ensino da EFE não é novidade na história dessa disciplina escolar (Bracht, 2019), mas o fato de seu retorno como discursividade central na estruturação desse componente curricular revela um retorno ao passado recente que limita pensar a educação do corpo no tempo e espaço da educação física. Isto é, pensa esse espaço curricular como reprodução de ideal esportivo idílico sem considerar outras experiências variadas e amplas para além dos esportes institucionalizados. Isso porque o Impulsiona, conforme demonstramos na seção anterior, se insere em uma rede discursiva que atua no espaço-tempo dos currículos escolares sem questioná-los, estão preocupados com sua elaboração e implementação eficiente, em especial no que diz respeito à formação continuada dos professores de EFE. Todavia, esse tipo de formação, no caso da EFE, só busca mais eficiência no ensino do restrito modelo esportivo do esporte institucionalizado como se esse fosse sinônimo dessa disciplina na escola. Com isso ignora diferentes experiências de ensino das artes do corpo tratadas em boas práticas nesta disciplina escolar. De fato, o Impulsiona associa o esporte diretamente à EFE, entendendo-os como sinônimos:

Matemática, Português, História, Geografia... essas disciplinas são muito importantes para o desenvolvimento dos alunos. Mas e a Educação Física? O cartaz do Impulsiona com 20 razões para valorizar a Educação Física na escola vai mostrar para todo mundo como o esporte é essencial para os jovens! Você pode baixar o PDF gratuitamente, imprimir e colar no mural da sua escola (Impulsiona, 2020b).

Na Figura 3, assim como na missão do Impulsiona, revela-se o entendimento que o programa de EFE e o esporte, que, além de equipará-los, torna o esporte o meio para o desenvolvimento de uma série de competências emocionais, cognitivas e biológicas. Aqui temos a clareza nos efeitos milagrosos do esporte. Essa discursividade performática concebe o esporte como instrumento e remédio para vários dilemas da existência humana e da educação das novas gerações. Com nova aparência discursiva, o esporte como redenção, confunde-se mais uma vez com essa disciplina escolar, fenômeno que só encontra semelhança com o caso da ginástica no início do século XX (Bracht, 2019). Vale dizer que a perspectiva esportivizante foi duramente criticada no final do século passado pelas teorias críticas de currículo que passaram a entender o esporte como apenas um dos possíveis conteúdos a serem tratados pela EFE, assim como as lutas, as ginásticas, as danças, os jogos e outras experiências sensitivas e expressivas. 
Figura 3 - Cartaz do Impulsiona para valorizar a EFE.

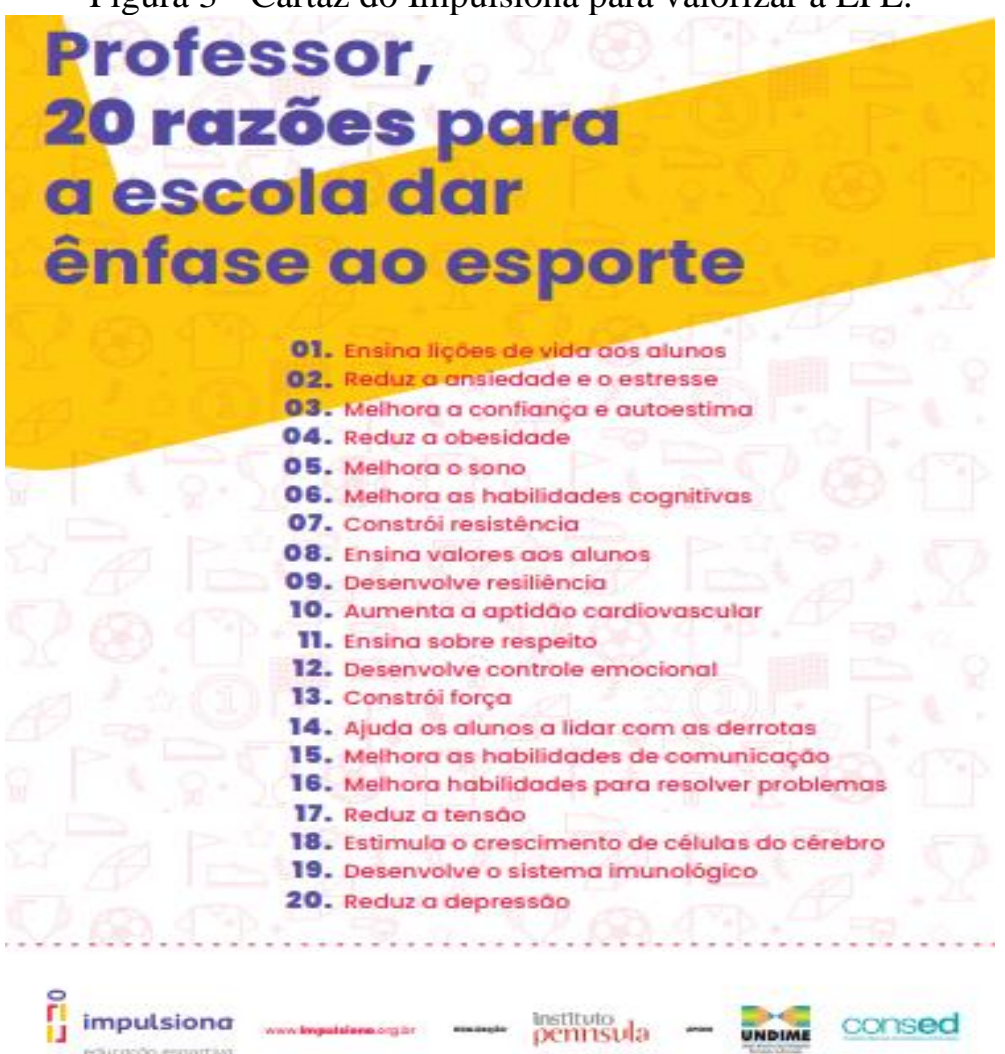

Fonte: Impulsiona (2020b).

Esses vinte benefícios educacionais tornam o esporte institucionalizado um bem inquestionável e um caminho para salvação do indivíduo e da humanidade. Temos aqui uma moralidade declarada alinhada ao credo neoliberal e o esporte, nesse sentido, é a metáfora por excelência desta perspectiva política e econômica. Estamos diante de uma ideologia normativa que cobra alinhamento dos indivíduos a uma moralidade secular que substituiu a religião.

Um aspecto determinante na concepção sobre esporte/EFE pelo Impulsiona é sua função utilitária e instrumental. À primeira vista, poderíamos afirmar não se tratar de uma novidade, uma vez que esporte e EFE há tempos andam de mãos dadas. Contudo, essa discursividade omite os diferentes sentidos assumidos pelo esporte desde sua inserção na EFE brasileira. $\mathrm{O}$ entendimento sobre o uso do esporte posto pelo Impulsiona é distinto das concepções anteriores do esporte como conteúdo dessa disciplina, pois não pensa o ensino esportivo na escola como um meio de promoção e de aparecimento de talentos esportivos, como parte da concepção embrionária do esporte e da EFE escolar na década de 1970; tampouco o pensa como um conteúdo que pode promover problematizações dos saberes constituintes desse fenômeno na sociedade capitalista, tal como concebido pelas teorias críticas de currículo no 
campo da EFE a partir da década de 1980. O esporte nessa nova versão é um caminho para formar personalidades e identidades alinhadas aos ideais neoliberais.

Para o Impulsiona, o esporte assume uma dimensão holística que pretende vender esse "instrumento" a partir de seus pacotes pedagógicos como meio de aquisição de várias competências emocionais, sociais, morais, físicas, neurofisiológicas, imunológicas e cognitivas/estratégicas perfeitamente alinhadas às demandas do mercado dominado pelo neoliberalismo econômico e cultural. O esporte seria uma ferramenta heurística para formar competências na tomada estratégica de decisão, no uso de inteligência emocional e na saúde física e mental. Temos que marcar que o esporte aqui é uma ferramenta de formação moral alinhada ao neoliberalismo.

Esse novo sentido do esporte no Impulsiona se articula com o discurso performático de poder presente nas reformas neoliberais de currículo. Na verdade, nada poderia ser mais representativo do neoliberalismo para a EFE do que associá-la ao esporte, visto que a configuração desse fenômeno na modernidade não deixou de refletir os valores liberais e seculares da igualdade de chances, especialização, racionalização, burocracia, quantificação, recordes e mérito (Guttmann, 1978). Nesse contexto, o esporte se tornou um aclamado símbolo de competição e de alta performance (Novaes; Triani; Telles, 2020). Como aponta Foucault (2008), no neoliberalismo a competição não é posta apenas como natural, mas como algo a ser reforçado entre os indivíduos como uma nova moralidade relacional.

Outrossim, o uso do esporte pelo Impulsiona também pode ser associado à performatividade do currículo por sua convergência com a BNCC, documento icônico das reformas neoliberais de currículo no Brasil. Segundo aponta Betti (2018), o texto de Educação Física da BNCC supervalorizou as práticas esportivas a despeito da recontextualização do esporte no campo do currículo da EFE a partir da década de 1980. A BNCC inflou esse conteúdo na base ao inaugurar, nos documentos curriculares nacionais, um novo tipo de classificação dos esportes, dividindo-o em nove subcategorias, estimulando o ensino de novas modalidades esportivas:

Marca: [...] patinação de velocidade, todas as provas do atletismo, remo, ciclismo, levantamento de peso etc.; Precisão: [...] bocha, curling, golfe, tiro com arco, tiro esportivo etc.; Técnico combinatório: [...] ginástica artística, ginástica rítmica, nado sincronizado, patinação artística, saltos ornamentais etc.; Rede/quadra dividida ou parede de rebote: [...] voleibol, vôlei de praia, tênis de campo, tênis de mesa, badminton e peteca; [...] basca, raquetebol, squash etc.; Campo e taco: [...] beisebol, críquete, softbol etc.; Invasão ou territorial: [...] basquetebol, frisbee, futebol, futsal, futebol americano, handebol, hóquei sobre grama, polo aquático, rúgbi etc.; Combate: [...] judô, boxe, esgrima, taekwondo etc. (Brasil, 2017, p. 215).

Ademais, a maior parte das práticas dos demais conteúdos curriculares (ginásticas, danças, lutas, jogos e práticas de aventura) também constituem práticas esportivas. Desse modo, o Impulsiona atende a demanda esportiva da BNCC ao oferecer cursos em parceria 
com o MEC sobre diferentes modalidades esportivas e sobre a própria BNCC. No Quadro1, apresentamos os cursos oferecidos pelo Impulsiona/MEC.

Quadro 1 - Categorização dos cursos do 'Impulsiona' em parceria com o MEC.

\begin{tabular}{|c|l|}
\hline Categoria & Cursos \\
\hline \multirow{2}{*}{ BNCC } & $\begin{array}{l}\text { BNCC na Prática: do currículo à sala de aula; } \\
\text { BNCC na Prática: como planejar as aulas de Educação Física. }\end{array}$ \\
\hline \multirow{3}{*}{ Esporte } & $\begin{array}{l}\text { Atletismo na Escola; Esporte Orientação; Explorando Novos } \\
\text { Esportes na Educação Física; Futebol de 5; Ginástica Artística; } \\
\text { Goalball; Golfe; Hóquei sobre a Grama; Miniatletismo; Movimento } \\
\text { Paralímpico: fundamentos básicos do esporte; Rugby. }\end{array}$ \\
\hline \multirow{2}{*}{ Pedagogia } & $\begin{array}{l}\text { Competências Socioemocionais na Educação Física; } \\
\text { Incentivando o Protagonismo Juvenil; } \\
\text { Metodologias Ativas na Educação Física; } \\
\text { O Papel do Coordenador Pedagógico na Educação Esportiva. }\end{array}$ \\
\hline
\end{tabular}

Fonte: os autores.

Notamos, assim, que os cursos sobre as diferentes modalidades esportivas do Impulsiona estão alinhados às novas modalidades citadas no texto da $\mathrm{BNCC}$, o que reforça a afinidade do documento com o Impulsiona. Essa supervalorização do esporte na BNCC provocou a inclusão de novas modalidades esportivas no currículo da EFE, muito embora não façam parte do repertório da formação nos cursos de Licenciatura em Educação Física. Segundo Rezer (2010) tradicionalmente os cursos de formação se limitam a esportes como: futebol/futsal; basquetebol; voleibol e handebol. Essa lacuna no campo formativo da EFE reforça o papel que o Impulsiona passa a ter junto às redes públicas de ensino para capacitar professores. De fato, a BNCC criou um mercado e passou a pautar a formação docente a partir de sua implantação.

Considerando as relações do Impulsiona com a vasta rede política descrita na seção anterior, argumentamos que o uso do esporte pelo Impulsiona está intimamente relacionado à superesportivização da BNCC e com a performatividade das reformas neoliberais de currículo. Nesse contexto, o Impulsiona funciona como um meio complementar da implementação da BNCC, na medida em que oferece as ferramentas necessárias para que o professor aprenda e aplique os conteúdos estabelecidos pelo documento normativo. Ao cumprir essa função, o Impulsiona extrapola o texto sobre EFE da Base e compartilha com os professores uma visão muito peculiar do esporte, eminentemente utilitária, heurística e moralizante.

\subsection{Silenciamento teórico e praticismo}

A relação do Impulsiona com a BNCC não se restringe aos cursos das mais variadas modalidades esportivas. O programa oferece dois cursos específicos sobre a BNCC. O primeiro, lançado oportunamente logo após a promulgação da Base, intitula-se "BNCC na 
Prática: do currículo à sala de aula". No ano seguinte foi lançado o segundo da série: "BNCC na Prática: como planejar as aulas de Educação Física". De acordo com o site do Impulsiona, o primeiro curso sobre BNCC foi o segundo mais acessado no ano de 2019 e o primeiro em $2020^{37}$. Esses cursos têm o objetivo de "facilitar a missão do professor; [...] tirar a teoria do papel e aplicá-la no dia a dia" ${ }^{38}$, o que reforça seu caráter prático.

A necessidade dos professores de realizarem as transposições da BNCC para a prática se justifica não apenas pela abrangência desse documento, ou por sua força de lei, mas sobretudo por se tratar de um documento eminentemente técnico. Para Neira (2018), o texto da Educação Física na BNCC ressuscita o vocabulário tecnocrático proveniente da psicologia da educação, estruturando o currículo da Educação Física a partir de competências, habilidades, dimensões e objetos do conhecimento. Com isso, a BNCC remete à "retomada dos princípios tecnocráticos, consubstanciados na prioridade concedida à racionalidade técnica em detrimento da criticidade" (NEIRA, 2018, p. 1). Além disso, temos que destacar que o discurso esportivizante é meio e fim de disseminação da moralidade neoliberal.

Para a Educação Física, a BNCC estipula dez competências gerais e 69 habilidades específicas, além das sete competências gerais da BNCC e de seis competências da área de Linguagens, na qual a Educação Física está inserida. O documento determina ainda suas "dimensões do conhecimento" para essa disciplina: experimentação; uso e apropriação; fruição; reflexão sobre a ação; construção de valores; análise; compreensão; e protagonismo comunitário; além de um vasto leque de conteúdo, em geral, sobre variadas modalidades esportivas (Brasil, 2017). A partir desse vasto repertório técnico, os cursos do Impulsiona se tornam um meio disponível para o professor que precisa adequar suas aulas à BNCC.

A linguagem adotada, tanto pela BNCC, quanto pelo Impulsiona, é um aspecto importante na compreensão do discurso performático que toma conta da narrativa da escola neoliberal. Segundo Taubman (2009), as reformas neoliberais se valem de um vocabulário específico, oriundo principalmente de termos emprestados do mercado e pelas ciências da aprendizagem. Como aponta Laval (2019, p. 67), esse "novo idioma da escola" transfere a lógica econômica para a lógica escolar, importando para os currículos escolares uma linguagem da economia. $\mathrm{O}$ esporte já nasce alinhado com essa gramática.

$\mathrm{O}$ uso do termo "competência" na BNCC, compartilhado pelo Impulsiona, representa bem esse novo idioma da escola. Essa terminologia é adotada amplamente pelo Impulsiona, inclusive na sua missão de "trabalhar importantes competências com crianças e jovens por meio dos valores do esporte" (Impulsiona, 2020c). Seguem, assim, o exemplo de diferentes instâncias de envergadura internacional, como a Organização das Nações Unidas para a Educação, a Ciência e a Cultura (UNESCO) e a Organização para a Cooperação e Desenvolvimento Econômico (OCDE), entre outras. As competências são também utilizadas no quadro das políticas públicas de currículo nacionais, que segundo Lemos e Macedo (2019, p. 57), são responsáveis por toda "uma atualização de uma retórica que submete a educação à linguagem econômica e a modelos sistêmicos".

Para Laval (2019), a substituição da palavra "conhecimento" por "competência" nos currículos escolares não é sem importância: seu uso, tanto na empresa, quanto na escola, "põe em questão a tarefa tradicional da escola, a transmissão de conhecimentos e a formação 
intelectual e cultural no sentido mais amplo do termo" (p. 76). Assim, assume-se a linguagem do mercado como mais conveniente para a eficácia que se espera das escolas. Na lógica das políticas neoliberais de currículo, as competências estão voltadas para a praticidade esperada da escola, essencial para as tarefas do mercado de trabalho, enquanto o conhecimento no sentido tradicional está para o nível da teoria.

No caso do Impulsiona, a natureza prática de seus cursos é uma característica marcante, conforme se observa na lista disponível no Quadro 1. Inclusive na categoria que nomeamos de "pedagógica", reconhecemos um direcionamento para as demandas práticas do professor/gestor de Educação Física. Em outras palavras, os cursos possuem como marca a aplicabilidade imediata ou, como prefere o Impulsiona, sua formação é voltada, no novo jargão do campo, para o "chão da escola".

O praticismo ao qual nos referimos se caracteriza por uma "[...] ação prático-utilitária visando a fins imediatos sem as mediações de análises de caráter histórico-social nos processos de intervenção social e política [...]" (Santos, 2011, p. 157). O que se silencia concomitantemente ao praticismo nos cursos/conteúdo do Impulsiona é a problematização desenvolvida pelas diferentes teorias de currículo nas últimas décadas. Aqui estamos nos referindo ao movimento renovador da Educação Física, que, a partir de meados da década de 1980, passou a entender a EFE não mais como "atividade física (na forma de exercícios, de esporte, de ginástica, etc.) e sim como a cultura corporal [...] por meio de uma reflexão sobre esses mesmos movimentos" e que propunha, em geral, uma educação crítica e reflexiva (Bracht, 2019, p. 136).

Esse silenciamento não é por acaso. Para Taubman (2009), a linguagem utilizada pelas reformas neoliberais de currículo vincula à docência um saber eminentemente prático/técnico, o qual se sobrepõe aos repertórios teóricos que problematizam o fazer docente. Por conseguinte, as práticas pedagógicas calcadas no neomarxismo, nas políticas de identidade, numa educação libertadora, entre outras, "parecem ter se derretido no ar ou se transformado em [simples] polêmicas [...]” (Taubman, 2009, p. 15). Nesse sentido, Li (2007) pontua que as soluções apontadas nas relações calcadas pelo neoliberalismo passam de questões profundamente políticas para questões eminentemente técnicas, deformando, assim, o conceito de educação como espaço de problematização e formação política.

A preferência por questões práticas da docência no Impulsiona e nas reformas neoliberais de currículo é bastante problemática, pois remete a uma simplificação dicotômica entre teoria e prática. Conforme argumenta Veiga-Neto (2015), não existe uma prática desacompanhada de uma teoria, pois as duas são indissociáveis, sendo impossível determinar uma anterioridade de uma sobre outra. Trata-se, portanto, de um falso problema, pois não é concebível pensar a "prática sem uma teoria que a abrigue", além do que a "própria teoria já é uma prática” (Veiga-Neto, 2015, p. 132). Para Popkewitz (2001, p. 88), "a prática não é externa à teoria, é sim um conceito teórico que conta a alguém como o mundo deve ser agregado e pensado". O efeito da visão dicotômica entre teoria e prática é a emergência de uma concepção do fazer docente como ação técnica e apolítica.

Se, por um lado, o praticismo do Impulsiona claramente pretende se afastar de um certo teoricismo acadêmico, por outro, aproxima-se de referenciais teóricos que versam "sobre 
uma formação profissional mais prática e mais dinâmica, com resoluções rápidas de casos concretos, com conteúdo mais técnico interventivo e menos abstrato" (Silva, 2019, p. 152). O silenciamento teórico ocorre apenas no nível discursivo, pois, na realidade, o que se observa é a substituição por outra perspectiva teórica e pedagógica que privilegia soluções rápidas e dinâmicas ao mesmo tempo que silencia as teorias críticas para pensar a educação.

Nesse contexto, além dos cursos já citados, o Impulsiona oferece aulas de Educação Física para serem compartilhadas e práticas modelares de ensino. São planos de aula prontos, compartilhamento de experiências docentes, atividades de sucesso aplicáveis aos diferentes contextos e contingências, como dias chuvosos, aulas a distância, com materiais adaptados etc. ${ }^{39}$. Nessa mesma linha, o Impulsiona realizou, em 2020 "webinários" com professores de EFE conhecidos por divulgarem aulas e atividades nas redes sociais para divulgar suas práticas em tempos de isolamento social (Mello; Novaes; Telles, 2020). Para Taubman (2009), a emergência das chamadas "melhores práticas" (best practices), ou "boas práticas", está relacionada ao discurso das reformas educativas neoliberais e fortalece a ideia de que o ensino independe do contexto local e de que as práticas podem ser universalizadas e exportadas.

A partir dessa mesma retórica, o Impulsiona segue o exemplo de outras instituições filantrópicas da nova socialização política e estimula a divulgação de práticas docentes de sucesso. A iniciativa de maior destaque é o Prêmio Professores do Brasil, organizado pelo MEC e financiado por diferentes atores filantrópicos ${ }^{40}$, no qual o Instituto Península e o Impulsiona são responsáveis pela categoria "Esporte como Estratégia de Aprendizagem". Os prêmios, além de adotarem uma estratégia competitiva tipicamente neoliberal e "esportiva", reforçam ainda mais o conceito de educação como prática performática e universalizável.

É preocupante o silenciamento do pensamento crítico no campo da Educação Física Escolar.

\subsection{A linguagem das ciências da aprendizagem}

A adoção de uma linguagem mais prática baseada em princípios mercadológicos não é, por si só, suficiente para entendermos como as reformas contemporâneas de currículo vêm problematizando a educação. Por mais que tais reformas se apoiem em um estatuto da prática, entendemos que não existe uma prática sem uma teoria que a suporte. Nesse sentido, Taubman (2009) aponta para a centralidade das ciências da aprendizagem (learning sciences) na concepção das práticas pedagógicas das reformas neoliberais de currículo nas últimas décadas:

As transformações são tão profundas que os termos que definem o que se concebe como ensino e formação docente parecem estabelecidos e não negociáveis. Esses termos, emanam das políticas econômicas neoliberais, das práticas corporativas, de agendas sociais neoconservadoras e, particularmente das ciências da aprendizagem, que estabelecem as práticas discursivas e não discursivas que constituem a educação atualmente (Taubman, 2009, p. 8, tradução nossa). 
Para esse autor, as ciências da aprendizagem formam um campo interdisciplinar composto por diferentes concepções e disciplinas, ou fragmentos de disciplinas, como "as ciências cognitivas, as neurociências, a ciência da computação, o desenvolvimentismo, a psicologia educacional, a linguística, a sociologia e a antropologia", sempre associadas a uma moral do mercado (Taubman, 2009, p. 160, tradução nossa). Em conjunto, esse arranjo transmite a ideia de que a aprendizagem é um processo lógico e linear que se confunde com a própria finalidade do processo educativo.

Entendemos que o Impulsiona está inserido nesse contexto das ciências da aprendizagem que pretendem conferir à educação uma linguagem atualizada pelos novos valores do mercado e que se nutre de diferentes perspectivas teóricas que transformam diferentes saberes em ferramentas para a obtenção de resultados cognitivos e técnicas socio emocionais. Nesse sentido, o Impulsiona (2020c) afirma que seu programa se baseia na seguinte estratégia pedagógica:

Devido aos avanços da neurociência, novas pesquisas científicas têm sido apresentadas em defesa da prática esportiva nas escolas, evidenciando relações positivas entre atividade física, funções cognitivas e desempenho escolar. A prática frequente de exercícios na infância e na adolescência pode ser benéfica para o desempenho cognitivo e a aprendizagem. De fato, uma correlação entre a prática de atividades esportivas e níveis de aprendizagem e inteligência foi observada em crianças em idade escolar [...]. Baseando-nos nos aspectos apresentados, constatamos que, independentemente das diferenças de idade, do status econômico e da cultura, a prática esportiva deve ser oferecida, uma vez que pode facilitar a aprendizagem e melhorar a saúde física e mental de crianças e jovens (grifo nosso).

A partir da leitura de sua estratégia pedagógica, constatamos que o Impulsiona se vale das ciências da aprendizagem, nomeadamente as neurociências, para fundamentar supostamente o processo de aprendizagem da EFE. Essa afirmação não se baseia apenas nesse trecho, mas em toda a retórica sobre aprendizagem proferida pelo Impulsiona. Assim, lançamos mão dos cursos do programa incluídos na categoria "Pedagogia" (Quadro 1) para compor o quadro geral dessa retórica: Metodologias Ativas na Educação Física; Competências Socioemocionais na Educação Física; Incentivando o Protagonismo Juvenil; e O Papel do Coordenador Pedagógico na Educação Esportiva. De forma geral, esses cursos representam os novos referenciais teóricos que destacam um fazer docente mais dinâmico, técnico, interventivo e, inclusive, mais gerencial. A moralidade neoliberal se revela nessas ações que devem ser antes de tudo práticas e eficazes.

Dentre esses cursos, destacamos o Metodologias Ativas na Educação Física. Segundo informações do site $^{41}$ do Impulsiona, o curso foi lançado em 2018 durante o XVII Congresso de Ciências do Desporto e Educação Física dos Países de Língua Portuguesa, em parceria com o professor Ricardo Catunda, da Universidade Estadual do Ceará (UECE). Além de figurar entre os dez mais acessados nos anos de 2019 e $2020^{33}$, o curso é um dos poucos 
ministrados presencialmente pelo Impulsiona em escolas públicas das secretarias de educação parceiras ${ }^{42}$.

O destaque que conferimos a esse curso é motivado pelo protagonismo das metodologias ativas na narrativa das instituições filantrópicas que atuam nas reformas neoliberais de currículo. Trata-se de uma verdadeira avalanche discursiva, que traz à tona o vocabulário das metodologias ativas para o campo da educação: ensino híbrido; sala de aula invertida; peer instruction; PBL, ou project based learning (aprendizagem por meio de projetos ou de problemas); TBL, ou team-based learning (aprendizagem por times); WAC, ou writing across the curriculum (escrita por meio das disciplinas); study case (estudo de caso); entre outras.

As metodologias ativas prezam por um novo modelo de educação e vem se integrando ao vocabulário dos que atuam no campo da educação, o que é potencializado pelas novas organizações filantrópicas $^{43}$. Para Silva (2019), as metodologias ativas criticam o tradicionalismo do ensino formal, alegando que o modelo tradicional não corresponde à realidade e, sem meias palavras, que ele não atende às demandas do mercado:

[...] a escola padronizada, que ensina e avalia a todos de forma igual e exige resultados previsíveis, ignora que a sociedade do conhecimento é baseada em competências cognitivas, pessoais e sociais, que não se adquirem da forma convencional e que exigem proatividade, colaboração, personalização e visão empreendedora (Moran, 2015, p. 16).

Assim, a linguagem das ciências da aprendizagem se articula com a linguagem do mercado. Isso se verifica no curso sobre metodologias ativas do Impulsiona no que diz respeito à concepção sobre a prática docente:

Um dos pontos mais importantes para o Professor de Educação Física é o fator metodológico - o como ensinar, que se concretiza com eficácia com base no conhecimento, nas habilidades e atitudes, fruto das competências adquiridas pelos professores na formação inicial e contínua (AVAMEC, 2021a, grifo nosso).

Emergem desse trecho do curso as caras noções de eficácia, competências e habilidades, também presentes nas falas do professor Catunda da UECE ao preconizar por aulas “" [...] mais eficientes, sem perda de tempo; [sua condução] tem que ser um processo econômico, um processo rápido; [...] o professor tem que ser um mobilizador o tempo todo; [...] a aprendizagem é a razão de uma aula" (AVAMEC, 2021a).

Essa última frase é significativa, uma vez que a aprendizagem centraliza o sentido do fazer docente nas ciências da aprendizagem, considerado técnico, e reduz a educação à aprendizagem. Para Veiga-Neto e Silva (2021), o efeito do foco exacerbado na aprendizagem é deixar a educação em um sentido amplo em segundo plano, desconsiderando a intersubjetividade do processo educativo como um todo ou, como afirma Macedo (2015, p. 899), "com vistas apenas a projetar a performance do aluno". 
Seguindo o fio condutor das ciências da aprendizagem, outro curso do Impulsiona que destacamos é o de 'Competências Socioemocionais na Educação Esportiva' (leia-se Competências Socioemocionais na EFE), não apenas por figurar entre os conteúdos mais acessados da plataforma em $2020^{44}$, mas principalmente pela sua relação com a BNCC. As competências socioemocionais ganharam destaque nesse documento na definição do termo "competências", entendidas como:

a mobilização de conhecimentos (conceitos e procedimentos), habilidades (práticas, cognitivas e socioemocionais), atitudes e valores para resolver demandas complexas da vida cotidiana, do pleno exercício da cidadania e do mundo do trabalho [...] mostrando-se também alinhada à Agenda 2030 da Organização das Nações Unidas (ONU)" (Brasil, 2017, p.8, grifo nosso).

Segundo Lemos e Macedo (2019), assim como observado no trecho acima, a adoção do termo "competências socioemocionais" na BNCC está alinhada a documentos exarados por organismos multinacionais já citados, como a Organização das Nações Unidas (ONU) e seu braço financeiro, o Banco Mundial, além da UNESCO e da OCDE. De acordo com Rodrigues (2015), as competências socioemocionais ainda não fazem parte do vocabulário específico das disciplinas escolares, mas vêm sendo amplamente utilizadas nos materiais de divulgação da base. No caso da Educação Física na BNCC, o termo não é diretamente empregado (Brasil, 2017), mas o curso do Impulsiona cumpre o papel de tecer essa relação:

As competências socioemocionais, assim como as competências cognitivas, buscam preparar o indivíduo da melhor forma possível, para enfrentar seus desafios pessoais e profissionais, em um mundo cada vez menos estável. A capacidade de lidar com essa instabilidade e a capacidade de adaptar-se a novas situações pode fazer a diferença na trajetória de vida dos alunos. E, do mesmo modo que as cognitivas, as socioemocionais são competências que podem ser aprendidas e praticadas na escola, e aprimoradas durante toda a vida (AVAMEC, 2021b).

De acordo com o curso do Impulsiona, oito das dez competências gerais da BNCC perpassam direta ou indiretamente pelas competências socioemocionais ${ }^{45}$ (AVAMEC, 2021b). Para a Educação Física, a "BNCC trata ainda de oito dimensões do conhecimento, que no âmbito da EFE se potencializarão no alcance do desenvolvimento das competências socioemocionais" (AVAMEC, 2021b). Por fim, o curso disponibiliza orientações para a avaliação dessas competências a partir de um questionário de 41 perguntas para serem respondidas numa escala de quatro pontos ${ }^{46}$. Desse modo, o curso sobre as "Competências Socioemocionais na Educação Esportiva” traz para essa disciplina concepções teóricas características das ciências da aprendizagem.

O Impulsiona, portanto, funciona não apenas como mero reprodutor da linguagem técnica da BNCC, ou apenas como uma extensão dela, conforme apontamos anteriormente; mais do que isso: amplifica os discursos performáticos que nela circulam. Isso faz da BNCC 
uma espécie de "cavalo de Troia", termo utilizado por Ball (2014, p. 118); trazendo de assalto para a educação o discurso da performatividade, o qual, por sua vez, é amplificado por diferentes atores sociais ${ }^{47}$.

Desse modo, o Impulsiona potencializa o discurso da performatividade presente tanto das ciências da aprendizagem quanto do mercado e que se naturaliza como uma alternativa moderna para "resolver" os problemas da educação. Especificamente, as ciências da aprendizagem cumprem o papel de legitimar cientificamente esse processo frente à sociedade e à comunidade escolar. As reformas neoliberais de currículo, baseadas numa determinada prática científica e nos procedimentos do mercado, é processada de forma, como afirma Foucault (2020, p. 65), "total, meticulosa e constante".

\subsection{Neo-higienismo}

Um último aspecto que queremos destacar no discurso da performatividade do Impulsiona está na sua missão de "tornar as escolas mais ativas". Conforme consta no site do programa, "escola ativa" é um termo proveniente de um movimento do Programa das Nações Unidas para o Desenvolvimento (PNUD), elaborado pela ONU, que, em 2016, publicou o Caderno de Desenvolvimento Humano sobre Escolas Ativas no Brasil. Esse caderno está inserido em uma série de outras ações do PNUD no Brasil ${ }^{48}$, que, por sua vez, "apoia os esforços da ONU para destacar os benefícios do esporte e da atividade física para o desenvolvimento humano de forma ampla" (Escolas e Comunidades Ativas, 2020).

Conforme destacamos, a ONU/Banco Mundial/UNESCO tem tido participação fundamental no "movimento global de reforma da educação (Germ)", em articulação com outros organismos multilaterais, como OCDE, produzindo documentos e pesquisas adotados globalmente, que, inclusive, serviram de referência para a BNCC (Lemos; Macedo, 2019). Especificamente na EFE, podemos incluir a publicação do Caderno de Desenvolvimento Humano sobre Escolas Ativas no Brasil, referência do Impulsiona.

Esse documento sobre escolas ativas no Brasil foi uma iniciativa do PNUD/ONU, do MEC e do Instituto Nacional de Estudos e Pesquisas Educacionais Anísio Teixeira (INEP) que tinha como "motivação comum (...) influenciar os mecanismos oficiais de pesquisa ligados ao tema do esporte e da educação, assim como as políticas públicas a eles relacionadas" (PNUD, 2016, p. 1). Para isso constituíram um comitê técnico composto pelos Ministérios da Educação, da Saúde e do Esporte; pelo Instituto Brasileiro de Geografia e Estatística (IBGE); e pela Rede Esporte pela Mudança Social (REMS), organização que reúne 150 instituições sociais (entre elas, o Atletas pelo Brasil, mantido pelo Instituto Península $^{49}$, e o já mencionado Instituto Trevo), além do apoio da marca esportiva Nike ${ }^{50}$ e do próprio PNUD ${ }^{51}$.

A partir das diretrizes definidas por essas organizações, uma equipe de pesquisadores foi reunida para realizar uma pesquisa em aproximadamente 600 escolas brasileiras sobre atividades físicas para, em seguida, propor "um conjunto de políticas capazes de fazer das escolas brasileiras, escolas mais ativas” (PNUD, 2016, p. 1). Dessa forma, a seleção dos 
pesquisadores ocorreu de acordo com o alinhamento com as diretrizes determinadas pelas instâncias superiores. Foram selecionados três professores da Escola de Educação Física da USP: Edison Manoel, Luiz Tourinho Dantas e Osvaldo Ferraz; e dois estatísticos pertencentes a outras instituições públicas. Os três pesquisadores possuem em comum uma afinidade, uns mais, outros menos, com o que ficou conhecido na EFE como "abordagem desenvolvimentista" ${ }^{52}$ no final do século passado.

Essa abordagem pedagógica, teoricamente apoiada nas teorias de desenvolvimento e Aprendizagem Motora, pensa a Educação Física como facilitadora da progressão normal do crescimento físico, do controle motor e do desenvolvimento fisiológico, cognitivo e afetivosocial. Tal concepção parte do pressuposto que o movimento humano era o meio e o fim no ensino da EFE. Apesar da grande repercussão no campo formativo, essa perspectiva pedagógica foi duramente criticada por diferentes teorias críticas de currículo da EFE em função de reduzir intervenção do professor aos aspectos biofisiológicos e comportamentais do organismo em nível motor (Bracht, 2019).

Observe que o novo documento sobre escolas ativas (PNUD, 2016) consiste, de alguma forma, em um retorno da abordagem desenvolvimentista na EFE, uma vez que o movimento e a fruição corporal se tornam elementos centrais, tanto no documento, quanto na abordagem metodológica, como pode ser observada pelo tipo de linguagem adotada pelos pesquisadores. Devemos destacar que a ênfase pedagógica dessa releitura no novo documento prioriza o movimentar-se como meio para o desenvolvimento da aptidão física dos alunos, secundarizando a progressão pedagógica idealizada na abordagem desenvolvimentistas. Há, dessa forma, um alinhamento dessa abordagem neodesenvolvimentista com os objetivos utilitários das escolas ativas do PNUD e do qual o Impulsiona se apropria.

Essa ideia de Escola Ativa será apresentada e discutida como um conceito que faça sentido em termos filosóficos - posto que dialoga com questões perenes do sentido de nossa existência - e científico - ao se pautar pelo que se conhece das relações multicausais entre o mover-se e o cérebro, o mover-se e a saúde, o moverse e a educação, e o desenvolvimento bio-psico-social (PNUD, 2016, p. 37).

Certamente existem peculiaridades nesse alinhamento discursivo, como um atual reconhecimento das discussões no campo do currículo:

As correntes citadas aqui [de currículo] foram elaboradas no âmbito da academia e buscavam construir visões de mundo, verdadeiros paradigmas para formatar um modo de olhar a realidade. Todavia, a realidade é multifacetada e, portanto, exige vários olhares. Na construção de uma concepção de Escola Ativa [...] trabalhamos na lógica da complementaridade entre correntes a partir da ideia de que não é possível compreender e promover o Desenvolvimento Humano com um único olhar, o da natureza ou da cultura (PNUD, 2016, p. 37).

Essa complementaridade entre as diferentes correntes de currículo desconsidera a complexidade dessa combinação, uma vez que elas disputam o próprio sentido da Educação 
Física. Assim, ao apaziguar as discussões no campo do currículo da EFE, o PNUD fixa um sentido que se pensa holístico e saudável para além dos debates no campo. Nesse caso, a EFE, por meio do esporte, torna-se um meio para obtenção de outros fins. De acordo com Neira (2021):

[...] sabe-se que a aquisição de um melhor condicionamento físico por meio de exercícios requer o atendimento aos princípios da individualidade biológica, sobrecarga, interdependência volume e intensidade etc., algo impraticável nas escolas, além de não figurar entre os seus objetivos.

Nesse sentido, a discussão sobre saúde e sedentarismo é reeditada no campo do currículo da Educação Física. Sem dúvida que a saúde tem sido um "tema fundamental no discurso legitimador da Educação Física [...], mas não como um núcleo gerador de sentido" (Bracht, 2019, p. 126 e 127). Assim a saúde orgânica volta à tona como dotadora de sentido e legitimidade da EFE e encontra respaldo, tanto no senso comum sobre o papel da disciplina, quanto no meio acadêmico (Farinatti; Ferreira, 2006), assim como em outras instâncias do campo como o CONFEF, outro parceiro do Impulsiona.

De acordo com Neira e Borges (2018), ao tratar de EFE ${ }^{53}$ o CONFEF reproduz "de forma aligeirada e desconexa concepções de ensino obsoletas e exalta a cultura da performatividade, balizada no discurso biológico do corpo saudável" (p. 571). Todavia, essas concepções encontram respaldo no modelo de vida ativa em nossa sociedade, reforçado pelo mercado de serviços da saúde, o que torna esses saberes legítimos na dimensão instrumental e naturalizados no âmbito da cultura. Como afirmava Lasch (1983), o "viver eternamente", ou o maior tempo possível, por meio da conservação do corpo, tornou-se um valor em si mesmo em uma dimensão cultural mais ampla.

Afirmamos que esse neo-higienismo representa um afastamento das discussões do campo do currículo e o alinhamento ao discurso da saúde ao mercado de consumo no campo da EFE (NOVAES et al., 2019). Essa concepção coaduna com a visão das escolas ativas compartilhada com o PNUD e com o Impulsiona, compondo um discurso neo-higienista que atrela a EFE à melhora da saúde e a qualquer meio que torne o corpo (organismo) ativo. Dessa forma, para Soares (2008), as pedagogias neo-higienistas "[...] não abandonam a mesma ideia, [...] de medir e calcular o gesto mais íntimo, de esquadrinhar a expressão mais singela, de elaborar uma cartografia da carne e controlar funções e eficácias” (p. 77).

O neo-higienista está presente nas textualidades do Impulsiona, PNUD e CONFEF, reforçando alguns dos postulados da EFE e reformulando outros:

Pode-se deduzir que a atividade física para a EFE brasileira supera uma intencionalidade restrita a ganhos para a saúde. Assume a influência e conhecimento para a adoção de um estilo de vida ativo nas fases posteriores de desenvolvimento, o estímulo para o desenvolvimento de funções executivas e, associado a isso, o desempenho acadêmico (PNUD, 2016, p. 39, grifo nosso). 
Nas palavras do Impulsiona: "a prática esportiva deve ser oferecida, uma vez que pode facilitar a aprendizagem e melhorar a saúde física e mental de crianças e jovens" (IMPULSIONA, 2020c). A EFE se torna um meio cujo caráter heurístico e utilitário justifica sua presença no currículo escolar. A EFE assim, milagrosamente, se legitima como instrumento de saúde e como formadora de competências que podem melhorar o desempenho acadêmico dos alunos, não se restringindo apenas ao combate ao sedentarismo. Em outras palavras, a EFE do Impulsiona se apoia em princípios neo-higiênicos voltados não apenas à performance física, mas também como auxiliar das performances cognitivas e socioemocionais.

O Impulsiona, portanto, reúne discursos tanto do campo da educação quanto da Educação Física para formar um sentido coeso e "moderno" para a disciplina na escola, Discurso esse sintonizado com o mercado do corpo e da saúde em nossa sociedade. Essa construção discursiva neo-higiênica combina diferentes peças para compor uma nova narrativa para a EFE: praticismo, utilitarismo, tecnocracia, ciências da aprendizagem e moralidade mercadológica. Destaca-se nessa narrativa um neo-higienismo de caráter mais holístico, que pretende desenvolver competências cognitivas, socioemocionais, sociais e corporais para atender às demandas de formação de capital humano exigidas pelo capital. Novas normatividades e moralidades do atual higienismo do corpo são produzidas para busca de adaptação, felicidade, saúde e consumo na sociedade de mercado. Com isso há um esvaziamento dos saberes e dos sentidos culturais que envolvem o componente curricular da Educação Física que tematiza a cultura corporal num sentido amplo de experiências para além dos esportes.

\section{Considerações finais}

Este texto expõe um duplo movimento de privatização e desestatização de uma narrativa sobre EFE pelo Impulsiona. Em um primeiro momento, demonstramos o alcance da complexa rede de influência do Impulsiona e de seus parceiros mais imediatos, revelando como o protagonismo dessa rede caracteriza um tipo muito específico de privatização pautada no filantrocapitalismo. Em seguida, procuramos desnaturalizar a narrativa de uma Educação Física neoliberal, percebida quando se apresenta atravessada por um ideal performático assumindo contornos esportivizantes, acríticos, tecnocráticos e neo-higiênicos.

Tememos que esses contornos acarretem um esvaziamento curricular da EFE. A instrumentalização dessa disciplina escolar e do fazer docente descritas no texto se ancoram em pressupostos culturais da sociedade moderna, os quais naturalizam os discursos que incidem sobre a escola e seus currículos. Nesse sentido, o currículo da Educação Física não existe em um vácuo cultural; muito pelo contrário: são os aspectos econômicos, políticos, sociais e culturais que determinam as formas assumidas pelas disciplinas escolares frente à sociedade. Não por acaso, as orientações propostas pelo Impulsiona dialogam com orientações para as reformas nos currículos operadas com o ventury philantropy, como a 
introdução de "habilidades socioemocionais" apregoada por instituições filantrópicas como o Instituto Ayrton Senna e potencializada pela OCDE.

Por fim, destacamos que é no conjunto das relações de poder da rede do Impulsiona (práticas não discursivas) com os saberes que nela circulam (práticas discursivas) que se constitui uma nova racionalidade política neoliberal para a EFE. Dessa forma, para Foucault (2014, p. 30), poder e saber estão diretamente implicados, pois "não há relação de poder sem constituição correlata de um campo de saber, nem saber que não suponha e não constitua ao mesmo tempo relações de poder", produzindo formas de pensar, agir e viver específicas. Parafraseando o filósofo, isso não significa que não há nada a ser feito; diversamente, há muito a ser feito.

\section{Notas:}

1. Doutrina econômica e política que se baseia na absoluta liberdade de mercado e é avessa à intervenção estatal na economia e mesmo na gestão de serviços públicos, esses também podem ser gerenciados pela inciativa privada. Em síntese, o estado deve ser mínimo e apenas gerir os recursos em favor da suposta gestão eficiente e mais econômica da iniciativa privada em todos os setores da economia.

2. O termo Germ implica numa crítica ao modelo de tais reformas, sendo empregado no sentido de um "vírus que mata a educação" (MACEDO, 2019a, p. 47).

3. Acesso em dez. de $2020 \mathrm{em}$ : https://www.institutopeninsula.org.br/conteudos/nossas-publicacoes/

4. Acesso em dez. de $2020 \mathrm{em}$ : https://www.narsp.com.br/quem-somos/

5. Acesso em jun. de 2021 em:https://www.prefeitura.sp.gov/cidade/secretarias/esporte/participacao_social/ index.php? $=197257$

6. Através de Leis de Incentivo ao Esporte, estadual (de São Paulo, regulamentada pelo Decreto 55.636 de 26/03/2010) e federal (Lei 11.428/06), pessoas jurídicas destinam recursos para incentivar projetos esportivos e recebem dedução ou abatimento do Imposto de Renda no ano seguinte.

7. Acesso em dez. 2020: https://institutosingularidades.edu.br/novoportal/

8. Acesso em dez. 2020: https://vivescer.org.br/o-que-e-a-vivescer/

9. Acesso em dez. 2020: https://www.institutopeninsula.org.br/conteudos/nossas-publicacoes/

10. Fundação social criada em 2002 pelo bilionário brasileiro Jorge Paulo Lemann. Essa fundação teve papel crucial para a implementação da BNCC, sendo considerada a fundação filantrópica mais poderosa do Brasil com papel de supervisão em inúmeras iniciativas e tendo aconselhado centenas de representantes nas esferas municipais, estaduais e federal, em posição pró currículo centralizador (TARLAU; MOELLER, 2020).

11. Braço social do Grupo Santillana, envolvido na publicação de livros didáticos, que, por sua vez, faz parte do grupo de mídia PRISA.

12. De acordo com a Lei de Responsabilidade Fiscal, o art. $14, \S 1^{\circ}$, a renúncia de receitas "compreende anistia, remissão, subsídio, crédito presumido, concessão de isenção em caráter geral, alteração de alíquota ou modificação de base de cálculo que implique redução discriminada de tributos ou contribuições, e outros benefícios que correspondem a tratamento diferenciado" (Brasil, 2005).

13. Entusiasta do esporte, Abílio Diniz foi campeão brasileiro de polo a cavalo e de motonáutica, tendo praticado boxe, judô, tênis, capoeira e levantamento de peso. Amante do futebol, montou um time (o Audax) que disputa competições oficiais. Acesso em nov. 2020 em: http://abiliodiniz.com.br/esporte-traz- 
reputacao/\#: :text=Na\%20

juventude $\% 2 \mathrm{C} \% 20$ foi $\% 20$ campe $\% \mathrm{C} 3 \% \mathrm{~A} 3 \mathrm{o} \% 20$ brasileiro,Audax $\% 2 \mathrm{C} \% 20 \mathrm{para} \% 20$ disputar\%20competi $\% \mathrm{C} 3 \%$ A7\% $3 \% \mathrm{~B} 5$ es\%20oficiais

14. Acesso em nov. $2020 \mathrm{em}$ : https://economia.estadao.com.br/noticias/geral,abilio-diniz-investe-em-empresade-educacao-imp-, 1565183

15. Acesso em $20 \mathrm{dez} .2020 \mathrm{em}$ : http://www.peninsulapart.com.br/

16. Acesso em nov. $2020 \mathrm{em:} \mathrm{https://epocanegocios.globo.com/Informacao/Acao/noticia/2014/09/abilio-diniz-}$ investe-em-empresa-de-educacao.html

17. Acesso em 20 dez. 2020 em: https://www.mindlab.com.br/setor-publico/

18. Em 2018 a Ânima, com 85 mil alunos inscritos era a $8^{\text {a }}$ maior empresa de ensino superior privado no Brasil. Atualmente, a Anima possui aproximadamente 140 mil alunos inscritos. Acesso em maio $2021 \mathrm{em}$ : https://arte.folha.uol.com.br/mercado/2018/06/17/dez-maiores-do-ensino-superior/ https://animaeducacao.com.br/

19. Acesso em maio 2021 em: https://gife.org.br/instituto-peninsula-firma-parceria-com-o-mec-e-levaeducacao-esportiva-para-todo-o-pais/?lang=en

20. Acesso em jan. $2021 \mathrm{em}$ : https://avamec.mec.gov.br/\#/

21. Proinfo é o Programa Nacional de Tecnologia Educacional. Disponível em: http://e-proinfo.mec.gov.br/ eproinfo/interativo/acessar_espaco_sistema/acessar.htm. Acesso em dez. 2020.

22. "O Prêmio Professores do Brasil surgiu em 2005 a partir da união do Prêmio Qualidade na Educação Infantil, desenvolvido, desde 1999, pela Coordenação Geral de Educação Infantil (COEDI), em parceria com a Fundação Orsa e União Nacional de Dirigentes Municipais de Educação (UNDIME), com o Prêmio Incentivo à Educação Fundamental, desenvolvido, desde 1995, pela Coordenação Geral de Ensino Fundamental (COEF), em parceria com a Fundação Bunge e o Conselho de Secretários Estaduais de Educação (CONSED)". Disponível em: http://premioprofessoresdobrasil.mec.gov.br/. Acesso em jun. de 2021.

23. Acesso em dez. $2020 \mathrm{em}$, respectivamente: https://www.seduc.ce.gov.br/2018/11/09/programa-impulsionae-seduc-fecham-parceria/; e https://www.confef.org.br/extra/revistaef/arquivos/2018/N67_MAR\% C3\%870/ Revista_Confef_67_PROGRAMA\%20FORTALECE.pdf

24. Acesso em $22 \mathrm{dez} .2020 \mathrm{em}$ : https://impulsiona.org.br/impulsiona-congresso-internacional/

25. Acesso em jan. $2021 \mathrm{em}$ : https://impulsiona.org.br/1o-congresso-de-educacao-esportiva/

26. Disponível em: https://www.facebook.com/InstitutoTrevo. Acesso em: 30 dez. 2020.

27. Recorte de cartaz de divulgação do evento recebido dos organizadores pelos autores.

28. Dentre as várias parcerias descritas, o Impulsiona apresenta sem seu site os seguintes parceiros institucionais: CONSED, Secretaria de Estado da Educação de Minas Gerais, Ministério da Educação, 
Prefeitura de São Paulo e UNDIME. Disponível em: https://impulsiona.org.br/sobre/\#parceiros. Acesso em dez. 2020.

29. As parcerias citadas estão disponíveis nos sites da UNDIME e do CONSED, disponíveis em: http://undime.org.br/ e http://www.consed.org.br/parceiros. Acesso em: jun. 2021.

30. Acesso em dez. 2020 em: https://www.institutopeninsula.org.br/wp-content/uploads/2020/10/relatorioanual-2019.pdf

31. Acesso em dez. 2020 em: https://impulsiona.org.br/sobre/\#parceiros

32. Instituição filantrópica criada em 1994, voltada para que pessoas com deficiência tenham educação de qualidade em escolas comuns.

33. Acesso em dez. $2020 \mathrm{em}$ : https://www.confef.org.br/extra/revistaef/arquivos/2018/N67_MAR\%C3\%87O/ Revista_Confef_67_PROGRAMA\%20FORTALECE.pdf

34. Acesso em dez. $2020 \mathrm{em}$ : https://www.confef.org.br/confef/comunicacao/boletim/1816

35. Acesso em jan. 2021 em: https://www.confef.org.br/extra/revistaef/arquivos/2018/N69_DEZEMBRO/7.pdf

36. Figura elaborada pelos autores em editor de imagens. Não foi utilizado nenhum software específico para detectar relações de incidência ou de mutualidade, uma vez que a finalidade foi o mapeamento da rede, assim como realizado por Ball (2014).

37. Acesso em jan. $2021 \mathrm{em}$ : https://impulsiona.org.br/top-10-impulsiona/ e através mensagem recebida por email cadastrado na plataforma do Impulsiona em 05 jan. 2021, intitulada “Top 10 do Impulsiona em 2020".

38. Acesso em jan. $2021 \mathrm{em}$ : https://impulsiona.org.br/bncc-na-pratica/

39. Acesso em dez. $2020 \mathrm{em}$ : https://impulsiona.org.br/conteudos-pedagogicos/

40. Ver a vasta lista de apoiadores do Prêmio Professores do Brasil em: http://premioprofessoresdobrasil.mec.gov.br/parceiros. Acesso em dez. 2020.

41. Acesso em jan. $2021 \mathrm{em}$ : https://impulsiona.org.br/metodologias-ativas-em-parceria-com-ricardo-catunda/

42. Nos dias 22 e 23 de outubro de 2019, ocorreu em Belo Horizonte um curso de formação sobre Metodologias Ativas na Educação Física, no qual participaram 47 representantes das Superintendências Regionais de Ensino. Acesso em jan. 2021 em: https://sreitajuba.educacao.mg.gov.br/index.php/banco-de-noticias/9noticias/161-profissionais-da-sre-itajuba-participam-do-curso-metodologias-ativas-na-educacao-fisica

43. Consubstanciado na publicação de livros, cursos de extensão e pós-graduação (como a pós-graduação Latu Sensu sobre metodologias ativas oferecida pelo Instituto Singularidades), reportagens, entre outras ações das novas instituições filantrópicas. Outro exemplo é uma reportagem da Fundação Lemann intitulada "6 Aprendizados sobre Inovação e Diversificação de Ensino”. Acesso em jan. 2021 em: https://fundacaolemann.org.br/noticias/6-aprendizados-sobre-inovacao-e-diversificacao-de-ensino

44. Acesso em jan. $2021 \mathrm{em}$ : https://impulsiona.org.br/top-10-impulsiona/

45. Mais especificamente as competências 1, 4, 5, 6, 7, 8, 9 e 10 (ver páginas 9 e 10 em BRASIL, 2017).

46. São eles: Questionário de Avaliação de Competências Socioemocionais (QACSE) e Questionário de Avaliação de Competências Socioemocionais - Professores (QACSE-P). Acesso em jan. 2021 em: https://www.researchgate.

net/publication/268810970_Desenvolvimento_e_validacao_do_Questionario_de_Avaliacao_de_Compete ncias_Socioemocionaisversao_professores

47. De forma mais concreta nos agentes filantrópicos, citamos o curso desenvolvido pelas organizações sem fins lucrativos Porvir e Instituto Ayrton Senna. Acesso em jan. 2021 em: https://socioemocionais.porvir.org/

48. "O Projeto Escolas e Comunidades Ativas foi inspirado em uma experiência piloto realizada na cidade do Rio de Janeiro, entre 2014 e 2016; concebido e implementado por uma aliança de 8 parceiros dos setores 
público, privado, não governamental e agências de desenvolvimento". Acesso em jan. 2021 em: https://www.escolase comunidadesativas.org/o-projeto

49. Além do Instituto Península, Itaú e Gol são as mantenedoras dessa organização sem fins lucrativos que reúne atletas e ex-atletas pela "melhoria do esporte e, por meio do esporte, luta por avanços sociais no país" em ações com o Poder Público. Acesso em jan. de 2021 em: https://atletaspelobrasil.org.br/

50. Moeller (2018) demonstrou como a Nike se tornou uma das maiores especialistas do mundo no desenvolvimento saudável de meninas adolescentes, apesar de não possuir nenhum conhecimento prévio na área.

51. Acesso em jan. de 2021 em: http://rems.org.br/br/quem-faz-parte/

52. Edson Manoel é um dos quatro autores do livro 'Educação Física Escolar: Fundamentos de uma Abordagem Desenvolvimentista' (TANI et al, 1988). Luiz Dantas foi orientando no mestrado e no doutorado do professor Edson Manoel e publica trabalhos, na sua maioria, no campo da performance humana. Osvaldo Ferraz realizou mestrado com o professor Go Tani, mas suas pesquisas se voltaram posteriormente para o currículo.

53. Neira e Borges (2018) se referem a um documento intitulado "Recomendações para a EFE", disponível em: https://listasconfef.org.br/arquivos/publicacoes/RECOMENDACOES_PARA_A_EDUCACAO_FISICA_ ESCOLAR2.pdf . Acesso em jan. 2021.

\section{Referências}

ADRIÃO, T. A privatização dos processos pedagógicos: grupos editoriais e os negócios na educação básica. In: MARINGONI, G. et al (org.). O negócio da educação: aventuras na terra do capitalismo sem risco. São Paulo: Olho d'Água, 2017, p. 129-144.

ADRIÃO, T. Dimensões e formas da privatização da educação no Brasil: caracterização a partir de mapeamento de produções nacionais e internacionais. Currículo sem Fronteiras, v. 18, n. 1, p. 8-28, 2018.

ADRIÃO, T; DOMICIANO, C. A educação pública e as corporações: avanços e contradições em uma década de ampliação de investimento no Brasil. Revista de Financiamento da Educação, Porto Alegre, v. 8, n. 3, p. 1-18, 2018.

ADRIÃO, T; PERONI, V. A formação das novas gerações como campo para os negócios? In: AGUIAR, M.; DOURADO, L. F. (org.). A BNCC na contramão do PNE 2014-2024: avaliação e perspectivas. Recife: ANPAE, 2018, p. 49-54.

ADRIÃO, T. A influência de atores privados na educação paulista: a primeira geração da privatização. Políticas Educativas, Paraná, v. 13, n. 2, p. 96-108, 2020.

AVAMEC. Metodologias ativas na educação física. 2021a. Disponível em:

https://avamec.mec.gov.br/\#/instituicao/peninsula/curso/1102/unidade/541/acessar?continue=true. Acesso em: 15 jan. 2021.

AVAMEC. Competências socioemocionais na educação esportiva. 2021b. Disponível em: https://avamec.mec.gov.br/\#/instituicao/peninsula/curso/133/unidade/169/acessar?continue= true. Acesso em: 15 jan. 2021.

AVELAR, M.; BALL, S. Mapping new philanthropy and the heterarchical state: the mobilization for the national learning standards in Brazil. International Journal of Educational Development, v. 64, p. 65-73, jan. 2017.

BALL, S. Performatividades e fabricações na economia educacional: rumo a uma sociedade performativa. Educação \& Realidade, Porto Alegre, v. 35, n. 2, p. 37-55, 2010. 
BALL, S. A constituição da subjetividade docente no Brasil: um contexto global. Revista Educação em Questão, Natal, v. 46 n. 32, p. 9-36, maio/ago. 2013.

BALL, S. Educação global S. A.: novas redes políticas e o imaginário neoliberal. Ponta Grosa: Editora UEPG, 2014.

BETTI, M. A versão final da Base Nacional Comum Curricular da Educação Física (Ensino Fundamental): menos virtudes, os mesmos defeitos. Rev. Bras. Educ. Fís. Escolar, ano IV, v. 1, p. 156-175, jul. 2018.

BISHOP, M.; GREEN, M. Philanthrocapitalism: how the rich can save the world. Londres: A\&C Black, 2008.

BRACHT, V. A educação física escolar no Brasil: o que ela vem sendo e o que pode ser. Ijuí: Editora Unijuí, 2019.

BRASIL. Lei de responsabilidade fiscal: lei complementar $\mathbf{n}^{\mathbf{0}} \mathbf{1 0 1}$, de 4 de maio de 2000. 4. reimpr. Brasília: Senado Federal, Subsecretaria de Edições Técnicas, 2005.

BRASIL. Ministério da Educação. Base Nacional Comum Curricular. Secretaria da Educação Básica, 2017.

DOWBOR, L. A Era do Capital Improdutivo. São Paulo: Autonomia Literária, 2017.

ESCOLAS E COMUNIDADES ATIVAS. O PNUD. 2020. Disponível em: https://www.escolasecomunidadesativas.org/o-pnud. Acesso em: 7 jan. 2020.

FARINATTI, P.; FERREIRA, M. S. Saúde, promoção da saúde e educação física: conceitos, princípios e aplicações. Rio de Janeiro: Eduerj, 2006.

FOUCAULT, M. Vigiar e punir: nascimento da prisão. 42. ed. Petrópolis: Vozes, 2014.

FOUCAULT, M. História da sexualidade 1: a vontade de saber. São Paulo: Paz e Terra, 2020.

GUTTMANN, A. From ritual to record: the nature of modern sports. New York: Columbia University Press, 1978.

IMPULSIONA. Tudo sobre educação esportiva. 2020a. Disponível em: https://impulsiona.org.br/. Acesso em: 22 dez. 2020.

IMPULSIONA. 20 razoes para praticar esportes na escola. 2020b. Disponível em:

https://impulsiona.org.br/20-razoes-para-praticar-esportes-na-escola/ . Acesso em: 8 jan. 2021.

IMPULSIONA. Sobre. 2020c. Disponível em: https://impulsiona.org.br/sobre/. Acesso em: 5 jan. 2021.

INSTITUTO PENÍNSULA. Relatório de Atividades 2019. 2019. Disponível em:

https://www.institutopeninsula.org.br/wp-content/uploads/2020/10/relatorio-anual-2019.pdf . Acesso em: 20 dez. 2020.

LASCH, C. A cultura do narcisismo: a vida americana numa era de esperanças em declínio. Rio de Janeiro: Imago Editora Ltda., 1983

LAVAL, C. A escola não é uma empresa: o neoliberalismo em ataque ao ensino público. São Paulo: Boitempo, 2019.

LAVAL, C. Foucault, Bourdieu e a questão neoliberal. São Paulo: Elefante, 2020.

LEMOS, G. A.; MACEDO, E. A incalibrável competência socioemocional. Linhas Críticas, Brasília, v. 25, p. 57-73, 2019.

LI, T. M. The will to improve: governmentality, development, and the practice of politics. Durham: Duke University Press, 2007.

LYOTARD, J. F. A condição pós-moderna. 16. ed. Rio de Janeiro: José Olympio Editora, 2015.

MACEDO, E. Base Nacional Curricular Comum: novas formas de sociabilidade produzindo sentidos para educação. e-Curriculum, São Paulo, v. 12, n. 3, p. 1530-1555, 2014.

MACEDO, E. Base nacional comum para currículos: direitos de aprendizagem e desenvolvimento para quem? Educação \& Sociedade, Campinas, v. 36, n. 133, p. 891-908, 2015. 
MACEDO, E. Por uma leitura topológica das políticas curriculares. Archivos Analíticos de Políticas Educativas, v. 24, n. 26, p. 1-23, 2016.

MACEDO, E. O que é a Base? E o currículo o que é? In: AGUIAR, M.; DOURADO, L. F. (org.). A BNCC na contramão do PNE 2014-2024: avaliação e perspectivas. Recife: ANPAE, 2018.

MACEDO, E. Fazendo a Base virar realidade: competências e o germe da comparação. Revista Retratos da Escola, Brasília, v. 13, n. 25, p. 39-58, jan./maio 2019a.

MACEDO, E. A educação e a urgência de "desbarbarizar” o mundo. e-Curriculum, São Paulo, v. 17, n. 3, p. 1101-1122, jul./set. 2019 b.

MELLO, J. G.; NOVAES, R.; TELLES, S. Educação física escolar a distância: possibilidades de atuação na educação básica. EaD em Foco, Rio de Janeiro, v. 10, n. 3, e1094, 2020.

MOELLER, K. The gender effect: capitalism, feminism, and the corporate politics of development. Berkeley: University of California, 2018.

MORAN, J. Mudando a educação com metodologias ativas. In: SOUZA, C.; MORALES, O. (org.). Convergências midiáticas, educação e cidadania: aproximações jovens. PG: Foca Foto-PROEX/UEPG, 2015. p. 15-33.

NEIRA, M. Incoerências e inconsistências na BNCC de Educação Física. Rev. Bras. Ciênc. Esporte, v. 40, n. 3, p. 215-223, 2018.

NEIRA, M.; BORGES, C. C. Esquadrinhar e governar: análise das recomendações do CONFEF para a educação física escolar. Educação \& Realidade, Porto Alegre, v. 43, n. 2, p. 571-590, 2018.

NEIRA, M. Negacionismo científico no ensino de educação física. Jornal da USP, São Paulo, 28 jan. 2021. Disponível em: https://jornal.usp.br/artigos/negacionismo-cientifico-no-ensino-de-educacao-fisica/

NOVAES, R.; TRIANI, F.; TELLES, S. A educação física na Base Nacional Comum Curricular: desconstruindo o discurso neoliberal. Revista Humanidades \& Inovação, Palmas, v. 7, n. 10, p. 70-84, 2020.

NOVAES, R.; TRIANI, F.; SOARES, A. J.; TELLES, S. Educação física escolar S.A.: mudanças e subjetividades na norma corporativa. Revista Educação \& Sociedade, Campinas, v. 42, e233849, 2021.

NOVAES, R.; LUTZ, T.; TRIANI, F.; TELLES, S. Educação física escolar no discurso imagético do Conselho Federal de Educação Física. Revista Temática, João Pessoa, ano XV, n. 12, 2019.

POPKEWITZ, T. S. Lutando em defesa da alma: a política do ensino e a construção do professor. Porto Alegre: Artmed Editora, 2001.

PNUD. Caderno de Desenvolvimento Humano sobre Escolas Ativas no Brasil: 2016. Brasília: PNUD: INEP, 2016.

REZER, R. Reflexões didático-pedagógicas acerca do ensino do esporte no processo de formação de professores de educação física. Movimento, v. 16, n. 1, p. 271-292, 2010.

RODRIGUES, C. E. Habilidades socioemocionais: a OCDE e seu projeto de governança educacional global. 37ª Reunião Nacional da ANPEd. Florianópolis: ANPEd. 2015.

SAHLBERG, P. Global Educational Reform Movement and its impact on schooling. In: MUNDY, Karen et al. (org.) Handbook of Global Education Policy. Nova Jersey: Wiley-Blackwell, 2016. p. 128-144.

SANTOS, C. M. Na prática a teoria é outra? Mitos e dilemas na relação entre teoria, prática, instrumentos e técnicas no serviço social. Rio de Janeiro: Lumem Juris, 2011.

SAVIANI, D. Histórias das ideias pedagógicas no Brasil. Campinas: Autores Associados, 2008.

SILVA, E. M. Crítica às metodologias ativas na formação profissional em serviço social. Temporalis, Brasília, ano 19, n. 38, p. 147-161, 2019.

SOARES, C. L. Pedagogias do Corpo: higiene, ginásticas, esporte. In: RAGO, M.; VEIGA-NETO, A. (Org.). Figuras de Foucault. 2. ed. Belo Horizonte: Autêntica, 2008. P. 75-86. 
TANI, G.; MANOEL, E. J.; KOKUBUN, E.; PROENÇA, J. E. Educação física escolar: fundamentação de uma abordagem desenvolvimentista. São Paulo, EPU/EDUSP, 1988.

TARLAU, R.; MOELLER, K. O consenso por filantropia: como uma fundação privada estabeleceu a BNCC no Brasil. Currículo sem Fronteiras, v. 20, n. 2, p. 553-603, 2020.

TAUBMAN, P. Teaching by numbers: deconstructing the discourse of standards and accountability in education. Nova York: Routledge, 2009.

VEIGA-NETO, A. Anotações sobre as relações entre teoria e prática. Educação em Foco, Juiz de Fora, v. 20, n. 1, p. 113-140, 2015.

VEIGA-NETO, A.; SILVA, M. Educação e estudos foucaultianos: uma entrevista com Alfredo Veiga-Neto. Reflexão e Ação, Santa Cruz do Sul, v. 29, n. 1, p. 254-263, 2021.

\section{Correspondência}

Renato Cavalcanti Novaes: Doutor em Ciências do Exercício e do Esporte pela Universidade do Estado do Rio de Janeiro (UERJ). Professor do Ensino Básico, Técnico e Tecnológico (EBTT) no Centro de Instrução Almirante Alexandrino (CIAA) e no Centro de Educação Física Almirante Adalberto Nunes (CEFAN) da Marinha do Brasil. Membro do Grupo de Pesquisa em Escola, Esporte e Cultura (GPEEsC/UERJ/UFRJ).

E-mail: rennovaes@ hotmail.com

Antonio Jorge Gonçalves Soares: Doutor em Educação Física e Cultura pela Universidade Gama Filho (UGF). Professor titular da Faculdade de Educação da Universidade Federal do Rio de Janeiro (UFRJ). Docente permanente do Programa de Pós-graduação em Educação, linha de pesquisa em Políticas Públicas e Instituições Educacionais. Bolsista Produtividade PQ/CNPq e Cientista do Nosso Estado FAPERJ. Líder do Laboratório de Pesquisas em Educação do Corpo (LABEC).

E-mail: ajgsoares@gmail.com

Theresa Adrião: Doutora em Educação pela Universidade de São Paulo (USP). Professora Livre Docente pela Universidade Estadual de Campinas (UNICAMP), onde atua no programa de pós-graduação em educação. Bolsista Produtividade PQ/CNPq. Coordena o Grupo de Estudos e Pesquisas em Políticas Educacionais (GREPPE/UNICAMP) e da Rede Latino-Americana e Africana de Pesquisadores em Privatização da Educação (ReLAAPPe).

E-mail: theadrião@gmail.com

Silvio de Cassio Costa Telles: Doutor em Educação Física e Cultura pela Universidade Gama Filho. Professor associado da Universidade Federal do Rio de Janeiro (UFRJ) e adjunto da Universidade do Estado do Rio de Janeiro (UERJ), onde atua, respectivamente, no Programa de Pós-graduação em Educação Física (PPGEF) e no Programa de Pós-graduação em Ciências do Exercício e do Esporte (PPGCEE). Líder do Grupo de Pesquisa Escola, Esporte e Cultura (GPEEsC/UERJ/UFRJ)..

E-mail: telles.ntg@terra.com.br

Texto publicado em Currículo sem Fronteiras com autorização dos autores. 